\title{
Sea-level change and facies development across potential Triassic-Jurassic boundary horizons, SW Britain
}

\author{
STEPHEN P. HESSELBO ${ }^{1}$, STUART A. ROBINSON ${ }^{1,2} \&$ FINN SURLYK $^{3}$ \\ ${ }^{1}$ Department of Earth Sciences, University of Oxford, Parks Road, Oxford OX1 3PR, UK \\ (e-mail: stephen.hesselbo@earth.ox.ac.uk) \\ ${ }^{2}$ Present address: Lamont-Doherty Earth Observatory of Columbia University, 61 Route 9W, Palisades, NY 10964, USA \\ ${ }^{3}$ Geological Institute, University of Copenhagen, Øster Voldgade 10, DK-1350 Copenhagen K, Denmark
}

\begin{abstract}
The Late Triassic to Early Jurassic aged succession of SW Britain (the Penarth and lower Lias Groups) comprises mudstone, sandstone and limestone strata deposited in a variety of marine to non-marine environments. Faunal and floral characteristics of these successions have led to the proposal that one location in SW England, St Audrie's Bay, should serve as the Global Stratotype Section and Point (GSSP) for the base of the Hettangian Stage and, thus, for the Triassic-Jurassic ( $\mathrm{Tr}-\mathrm{J}$ ) boundary. The sections of SW Britain have also been used previously to infer sea-level change history and relate this to potential kill mechanisms associated with the $\mathrm{Tr}-\mathrm{J}$ boundary mass extinction. Chemostratigraphic, biofacies and lithofacies data are used here to suggest alternative models of sea-level change in relation to possible $\mathrm{Tr}-\mathrm{J}$ boundary horizons in the sections of SW Britain. A sea-level lowstand surface of erosion is inferred to occur within the Cotham Member of the Lilstock Formation, a unit deposited in an environment that was often subaerially exposed. In contrast to previous interpretations, the top surface of the overlying Langport Member (here inferred to be deposited on a carbonate ramp of depositional or tectonic origin) represents a drowning event of at least regional extent. All horizons regarded as plausible levels at which to place the $\mathrm{Tr}-\mathrm{J}$ boundary based on fossil distributions lie within strata deposited during relative sea-level rise. However, it is doubtful whether the higher horizons proposed to mark the boundary faithfully record times of true biotic change on a global scale and, additionally, there is no positive evidence that sea-level fall had any relation to the genesis of proposed $\mathrm{Tr}-\mathrm{J}$ marker horizons. It is unlikely that sea-level fall played a significant role in the $\mathrm{Tr}-\mathrm{J}$ boundary extinctions in either a local or a global context.
\end{abstract}

Keywords: Triassic, Jurassic, extinction, sea-level change.

Period boundaries commonly mark episodes of major global environmental changes and this is undoubtedly true of the transition from the Triassic to the Jurassic (Wignall 2001; Hesselbo et al. 2002; Olsen et al. 2002 and references therein). These environmental changes occurred coincidentally with a period of accelerated extinction that may have been particularly intense some time in the Late Triassic and at the RhaetianHettangian (Triassic-Jurassic) boundary (Benton 1986; Hallam 2002; Sephton et al. 2002). The extinctions took place at about the same time as extraterrestrial impacts at c. $214 \mathrm{Ma}$ in the late Triassic (Hodych \& Dunning 1992; Spray et al. 1998; Walkden et al. 2002) and massive volcanism at c. $200 \mathrm{Ma}$ at the TriassicJurassic boundary (McHone 1996; Marzoli et al. 1999; Hames et al. 2000; Pálfy et al. 2000; Hesselbo et al. 2002), but precise cause and effect relationships are unproven. Certainly, the principal geological event at the Triassic-Jurassic ( $\mathrm{Tr}-\mathrm{J}$ ) boundary (even as broadly defined) was the extrusion of vast quantities of basalt as the Central Atlantic split, ending an era in which global palaeogeography was dominated by the existence of a single supercontinent, Pangaea (Fig. 1). With regard to the Central Atlantic Magmatic Province volcanism, it has been suggested that a large region of western Europe was subject to rapid sea-level fall and subsequent rise (Hallam 1988, 1997) and, additionally, it has been proposed that it was these sea-level changes that were responsible for the significant biotic changes that mark the period boundary (e.g. Hallam \& Goodfellow 1990; Hallam 1995, 2002; Hallam \& Wignall 1997; Tanner et al. 2001).
The area of SW Britain has been important to studies of the $\mathrm{Tr}-\mathrm{J}$ boundary events because striking changes in palaeoenvironment are evident from the successions and these have strongly guided interpretations of regional, and even global, sea-level changes. Additionally, it has recently been proposed that these successions contain a record of a large extraterrestrial body impact (Simms 2003).

The aims of the present paper are: (1) to review and clarify interpretations of relative sea-level change for the $\operatorname{Tr}-\mathrm{J}$ boundary interval in a key area of SW Britain where marginal marine facies highly sensitive to sea-level change were developed; (2) to place in precise stratigraphic context suggested previous interpretations for the position of the Triassic-Jurassic boundary in these sections and to discuss their merits.

\section{Geological setting}

The $\mathrm{Tr}-\mathrm{J}$ boundary beds of SW England and south Wales were laid down in a series of extensional basins with a predominant east-west orientation (Fig. 1). The structural style comprised half-grabens bounded by faults whose dip and downthrow were mostly to the south. Environments of deposition in the Norian were lacustrine and commonly evaporitic, but during the Rhaetian the conditions became mostly marine. Marine environments were maintained in the area through the subsequent Early Jurassic. Palaeozoic basement rocks cropped out along the northern margin of the depositional area and these formed an elongate 


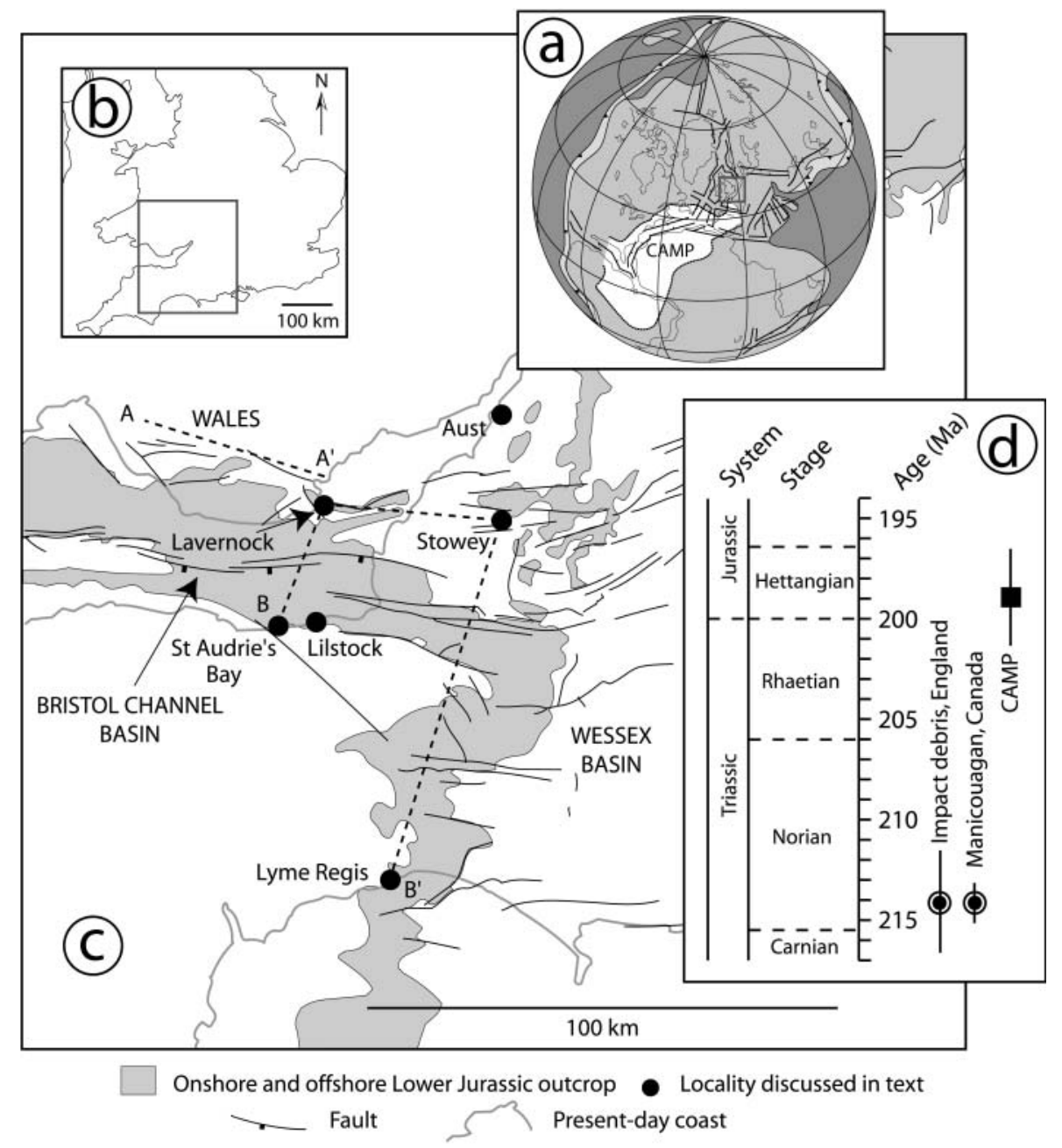

Fig. 1. (a) Global palaeogeography at the Triassic-Jurassic boundary (after Ziegler 1990) showing extent of Central Atlantic Magmatic Province (CAMP: from McHone 2000). (b) Location of study area. (c) Principal localities referred to in the text, shown relative to Lower Jurassic onshore and offshore outcrop (data from BGS Geology of the United Kingdom, Ireland and the Adjacent Continental Shelf (south sheet) 1:1000 000). Lines of section refer to Figure $2\left(\mathrm{~A}-\mathrm{A}^{\prime}\right)$ and Figure $5\left(\mathrm{~B}-\mathrm{B}^{\prime}\right)$. (d) Stages and ages across the Triassic-Jurassic boundary and principal geological events. Time scale from Kent \& Olsen (1999) on the basis that the $\mathrm{Tr}-\mathrm{J}$ boundary is $200 \mathrm{Ma}$ (Pálfy et al. 2000). Age of Central Atlantic Magmatic Province from Marzoli et al. (1999) and impacts from Spray et al. (1998) and Walkden et al. (2002). region of high ground that was not finally buried until the MidJurassic (e.g. Fig. 2).

The principal localities in SW Britain for $\mathrm{Tr}-\mathrm{J}$ boundary strata are shown in Figure 1. The sections at Lyme Regis, St Audrie's Bay, Lilstock and Lavernock were described with exemplary accuracy and precision by Richardson (1905, 1906, 1911). St Audrie's Bay has become the focus of most modern detailed stratigraphic work because of good exposure and easy access.

\section{Environments of deposition and sea-level change}

In the following section the facies evidence for sea-level change in each lithostratigraphic unit is reviewed and new sedimentological and geochemical data are introduced where relevant. The lithostratigraphic scheme follows Warrington et al. (1980) (Figs. 3 and 4). Previously unpublished geochemical data include highresolution total organic carbon ( $\%$ TOC) and carbonate carbon (\% CARB) content for the St Audrie's Bay section (Fig. 4; method as described by Hesselbo et al. 2003). Also included in Figure 4 are carbon-isotope data from bulk organic matter previously published by Hesselbo et al. (2002) but shown in that study only against a generalized summary log. Our interpretations of relative sea-level change are illustrated in the form of standard systems tract nomenclature (e.g. as summarized by Rawson et al. 2002) in Figures 2 and 4.

\section{Mercia Mudstone Group, Blue Anchor Formation}

Williton Member. The Williton Member, of Rhaetian age, has its type section at St Audrie's Bay (Mayall 1981), where it is about $2 \mathrm{~m}$ thick (Figs. 3 and 4 ). The unit comprises a thinly laminated heterolith of mudstone and fine-grained sandstone. The base of the unit is an irregular erosion surface, and the immediately underlying deposits, interpreted by Mayall (1981) as topped by a firmground, are characterized by an abundance of Diplocraterion. Other marine trace fossils, together with marine bivalves, have been described from the unit as a whole (Mayall 1981). The environment of deposition is considered shallow marine based on the occurrences of these fossils, and it is recognized that this unit represents the initial Late Triassic marine transgression in SW Britain, which heralded the longer-term Early Jurassic sea-level rise (Mayall 1981).

\section{Penarth Group}

Westbury Formation. The Westbury Formation, also of Rhaetian age, is commonly about $10 \mathrm{~m}$ thick and comprises a regionally extensive marine unit of predominantly mudstone with interstratified beds of siltstone, phosphatic conglomerate and carbonate concretions (Richardson 1906, 1911). Locally the upper part grades into sandstone, as is the case at Lavernock in south Wales (Francis 1959; Wilson et al. 1990; Warrington \& Ivimey-Cook 

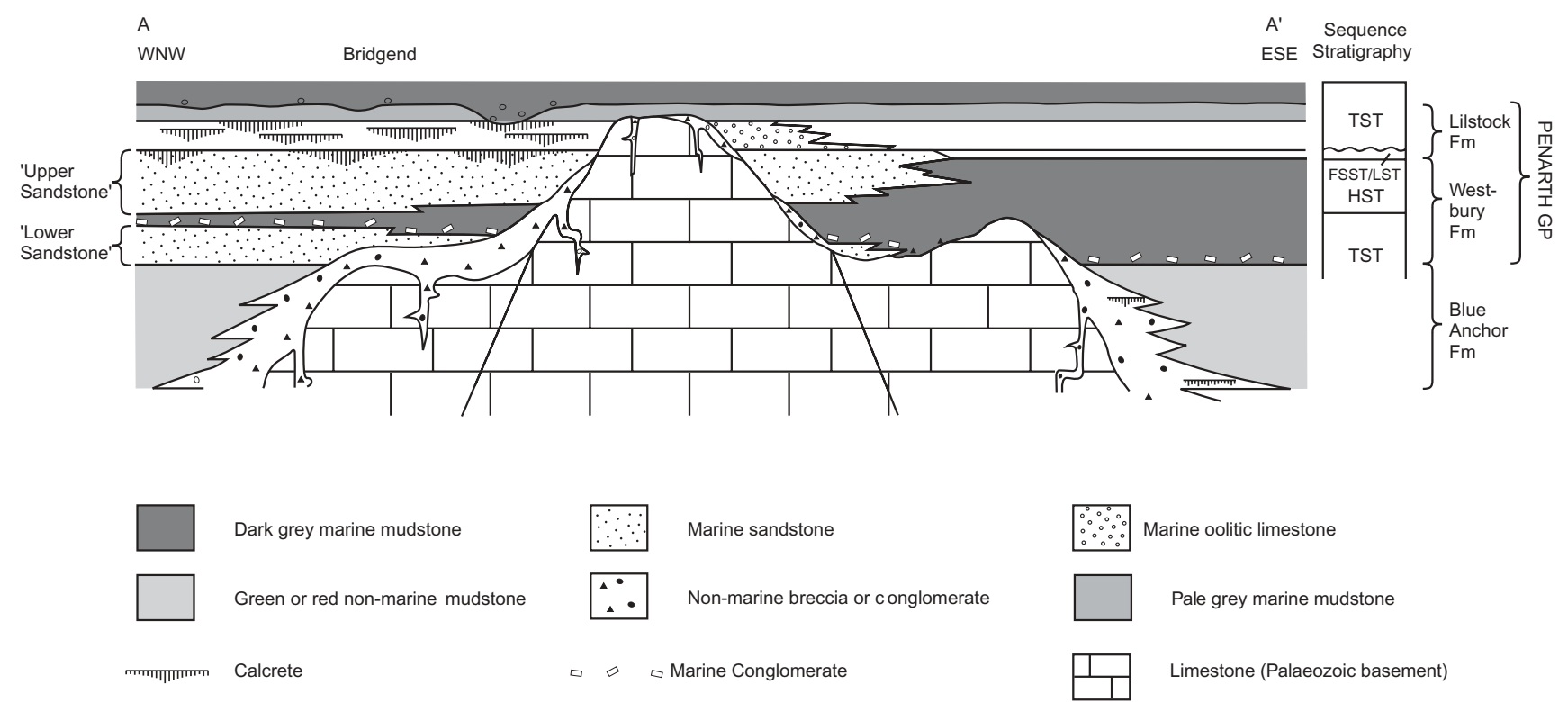

Fig. 2. Schematic cross-section across a basement high in south Wales (based upon Wilson et al. 1990). (Note within the Westbury Formation the development of a 'Lower Sandstone' interpreted as reflecting shoreface retrogradation and an 'Upper Sandstone' formed during progradation.) Sequence stratigraphic interpretation, this study. TST, transgressive systems tract; HST, highstand systems tract; FSST/LST, falling stage systems tract-lowstand systems tract.

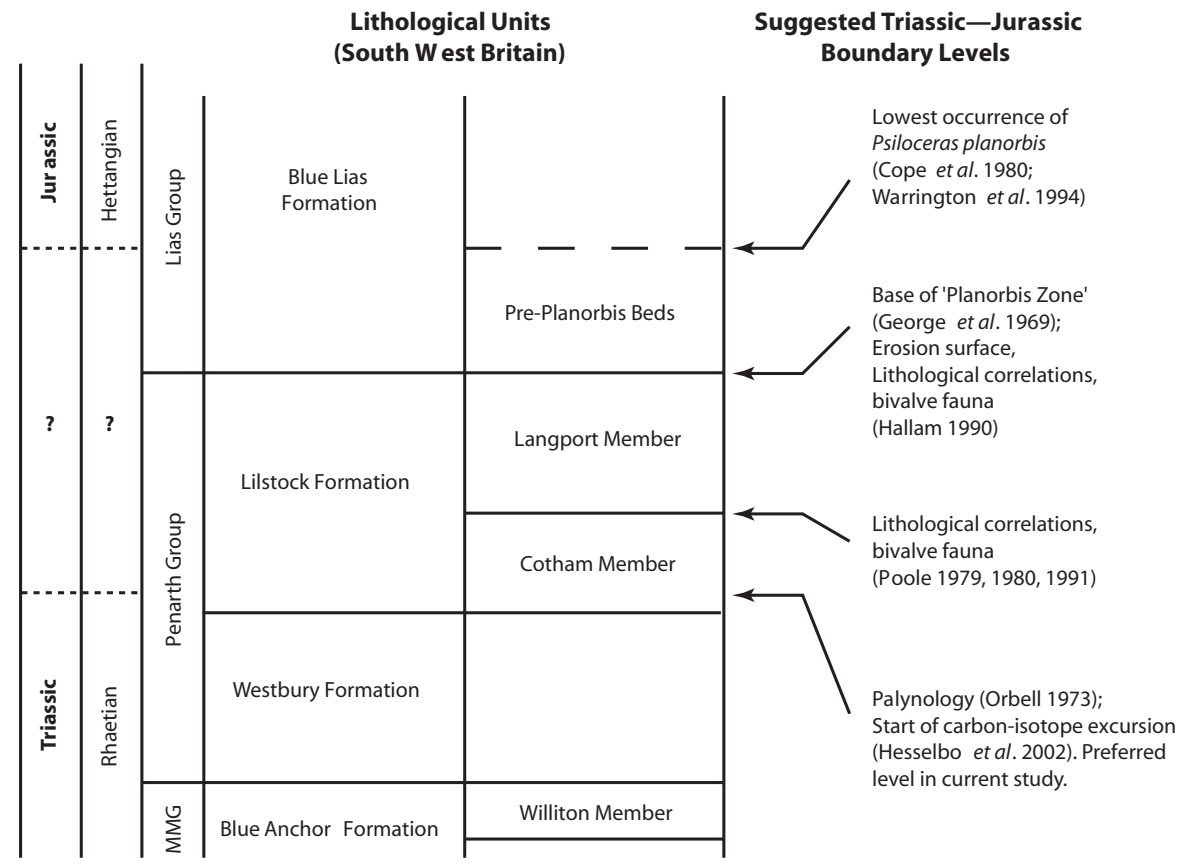

Fig. 3. Lithostratigraphic scheme of Warrington et al. (1980) and alternative Triassic-Jurassic boundary definitions, SW Britain. MMG, Mercia Mudstone Group.
1995). Although dark in colour, the formation as a whole is not particularly organic rich at St Audrie's Bay, and carbonate is restricted to discrete concretionary horizons, probably as a result of post-depositional dissolution because known calcitic macrofossils occur most commonly as empty moulds (Fig. 4; Macquaker acquaker 1984; Tuweni \& Tyson 1994). The sea was shallow and deposition took place under generally quiet-water offshore conditions, although periodically wave base impinged upon the sea floor as shown by the occurrence of wave-ripples (Macquaker 1994). The formation has been described as comprising a number of metre-scale coarsening-upward units capped by shell-beds and 'bone'-beds (Ivimey-Cook 1974; Macquaker 1994, 1999). A prominent bone-bed occurs at the base of the formation at many localities, for example at Aust in Avon (Radley \& Carpenter 1999), but not at the more expanded section at St Audrie's Bay (Fig. 4).

Bivalves are the most common and prominent fossils within the Westbury Formation and occur predominantly in shell-beds (Ivimey-Cook et al. 1999). Vertebrate debris is also fairly abundant in the lower part of the formation, and includes fish 


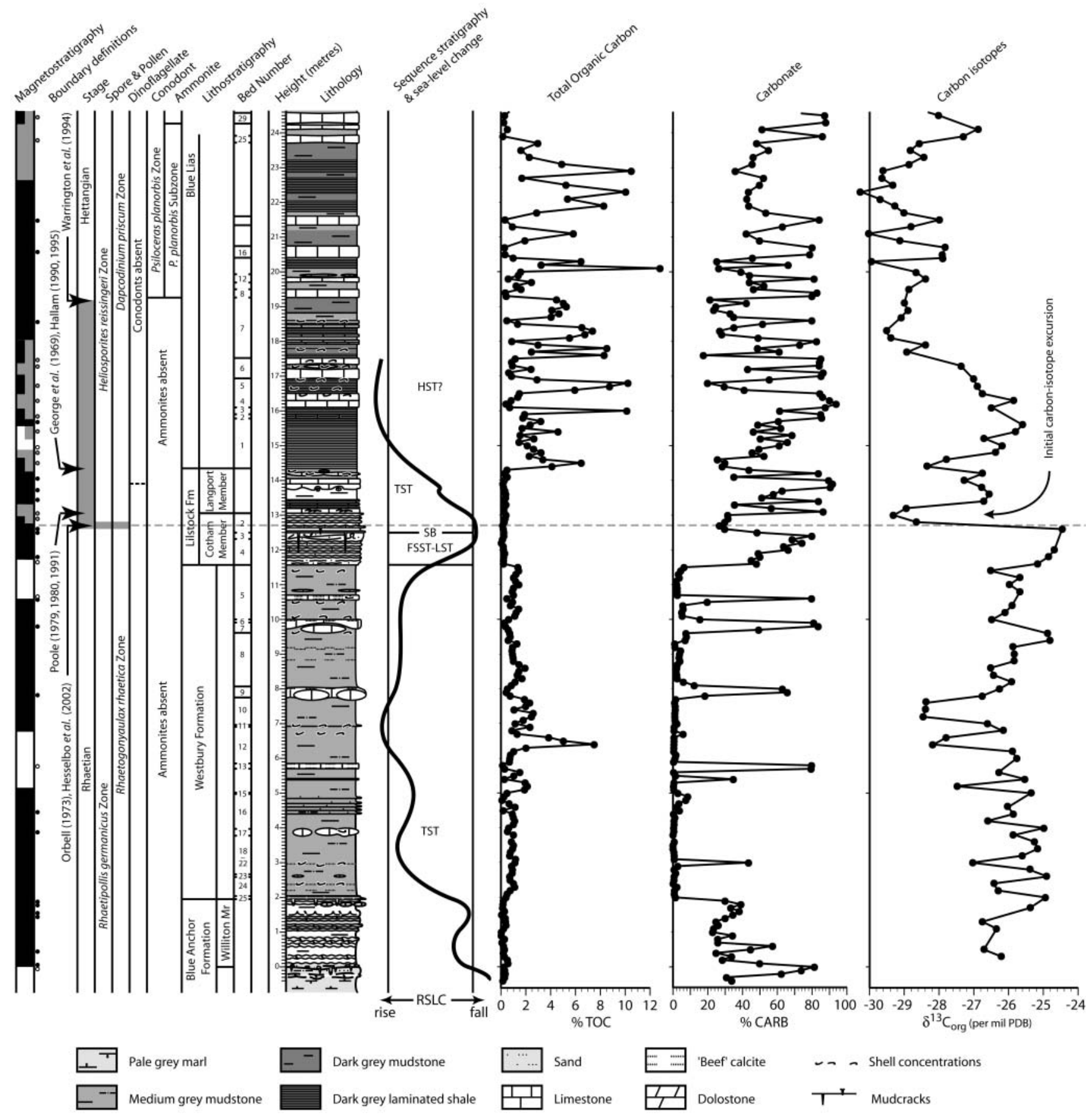

Fig. 4. Graphic log of the Tr-J boundary interval at St Audrie's Bay, Somerset. Magnetostratigraphy from Hounslow et al. 2001; M. W. Hounslow, in press.; boundary definitions according to George et al. (1969), Orbell (1973), Poole (1979, 1980, 1991), Hallam (1990, 1995) and Warrington et al. (1994). Spore and pollen and dinoflagellate zones follow Orbell (1973), Woollam \& Riding (1983) and Hesselbo et al. (2002). Conodont data from Swift (1999, pers. comm.). Ammonites from Warrington \& Ivimey-Cook (1995) and Bloos \& Page (2000). Westbury Formation and Cotham Member bed numbers from Richardson (1911). Lilstock Formation-Blue Lias Formation boundary after Whittaker (1978). Method for geochemical data as given by Hesselbo et al. (2003); most samples collected for geochemical analysis were excavated from the foreshore and all are unweathered. Sequence stratigraphy, this study. RSLC, relative sea-level change; TST, transgressive systems tract; FSST, falling stage systems tract; LST, lowstand systems tract; $\mathrm{SB}$, sequence boundary.

teeth and scales, and larger marine and terrestrial reptiles (Martill 1999). This material commonly occurs together with coarse siliciclastic sediment grains and phosphatic coprolites (e.g. Macquaker 1994; Martill 1999). The 'bone'-beds have been interpreted as winnowed lags formed during transgression (Hamilton 1977; Macquaker 1994). The organic matter content is mostly amorphous, particularly in the thin more organic-rich parts of the formation, but palynomorphs and phytoclasts 
predominate at some levels, such as the lowest metre or so of the formation (Thomas et al. 1993; Tuweni \& Tyson 1994).

The main part of the Westbury Formation was clearly deposited in deeper water compared with the underlying strata of the Williton Member, and probably further from the shoreline. There is no doubt, however, that the uppermost beds of the Westbury Formation at many localities represent a shallowing. This is particularly evident at Lavernock and Aust, where the deposits become coarser and lighter in colour towards the top of the formation. Occasional exposures in the vicinity of Bridgend, south Wales, are particularly instructive (Fig. 2). There, the lower and upper parts of the Westbury Formation comprise units known as the 'Lower Sandstone' and the 'Upper Sandstone' (Francis 1959), both of which can be traced laterally into more typical muddy Westbury Formation. The 'Upper Sandstone' shows all the characteristics typical of a prograding shoreface, including heterolithic siltstone and fine- to medium-grained sandstone with linsen and flaser bedding in the lower part, medium-grained sandstone beds in the middle with low-angle and hummocky cross-stratification, and an upper unit of sandstone lacking clear sedimentary structures but locally pebbly (Wilson et al. 1990).

A maximum flooding surface must thus lie somewhere within the middle of the Westbury Formation, but it is uncertain whether or not this coincides with the maximum TOC spike (Fig. 4), as has been suggested in many other similar examples. The main controls on organic carbon content are productivity and preservation, which are only indirectly related to sea-level change, and thus TOC maximum is not necessarily indicative of maximum flooding (e.g. Williams et al. 2001).

\section{Lilstock Formation}

Cotham Member. The lower member of the Lilstock Formation, the Cotham Member, comprises mudstone, fine-grained sandstone and limestone. The Cotham Member is of Rhaetian age, but possibly may be Hettangian at the top, depending on boundary definition (Fig. 3). In the area of SW Britain, the facies of the lower part of the Cotham Member differ somewhat from those of the upper part of the member and they are here considered separately.

The transition up from the Westbury Formation is in many places gradational, but this relationship is complicated by liquefaction and soft-sediment folding that has affected the lower Cotham Member at many locations in SW Britain and elsewhere; these strata are commonly referred to as the 'deformed bed' or 'slump bed' (Figs 5-7; Mayall 1983). The extremely widespread occurrence of in situ deformed strata in the lower Cotham Member has led Simms (2003) to suggest that the only plausible origin is massive regional shock caused by extraterrestrial impact.

In the vicinity of the modern Bristol Channel, the lower Cotham Member comprises a heterolithic facies of thinly interbedded siltstone and fine-grained sandstone, commonly waveripple laminated (Fig. 7; Mayall 1983). There are few fossils in the Cotham Member, but the bivalves Chlamys, Protocardia and Isocyprina present in the Westbury Formation also occur in the lower Cotham Member (Richardson 1911; Ivimey-Cook et al. 1999), supporting the interpretation that the lower Cotham Member represents simply a shoreface equivalent of the offshore deposits of the Westbury Formation.

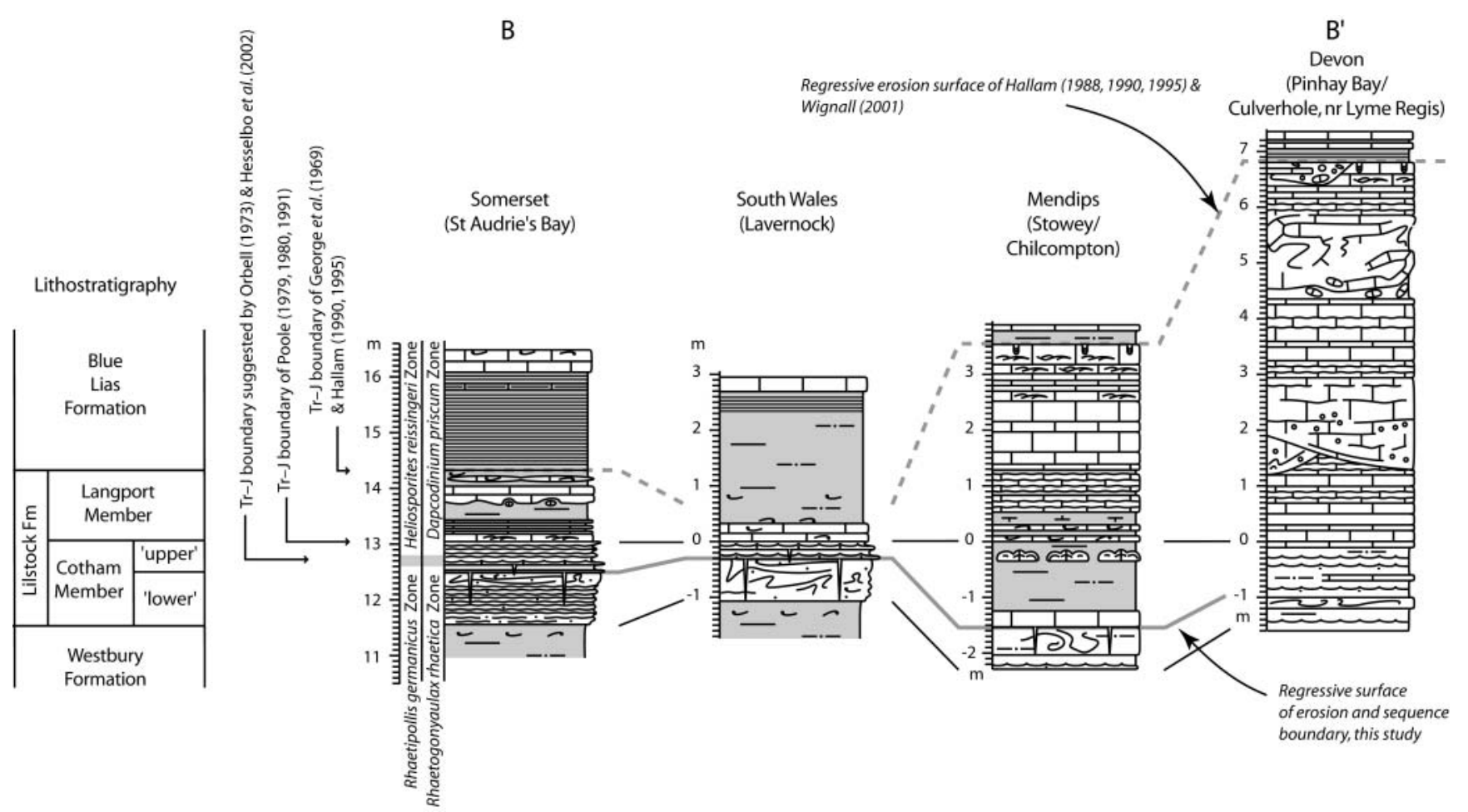

Fig. 5. Correlation between key SW British sections across the Tr-J boundary. The regressive surface of erosion of the present study is contrasted with the sea-level lowstand surface implied by Hallam $(1988,1990,1995)$ and Wignall (2001). The position of Hallam's lowstand surface at St Audrie's Bay is based on Hallam (1995, fig. 2). Somerset graphic log and biostratigraphy from Hesselbo et al. (2002) (see Fig. 4); south Wales and Mendips logs are based on new data, except for the lowest $1 \mathrm{~m}$ of the Mendips section,which is from Duffin (1980). Langport Member at Lyme Regis is from Hesselbo \& Jenkyns (1995), modified on the basis of Wignall (2001), and the Cotham Member is from Mayall (1983). (See Fig. 4 for key.) 


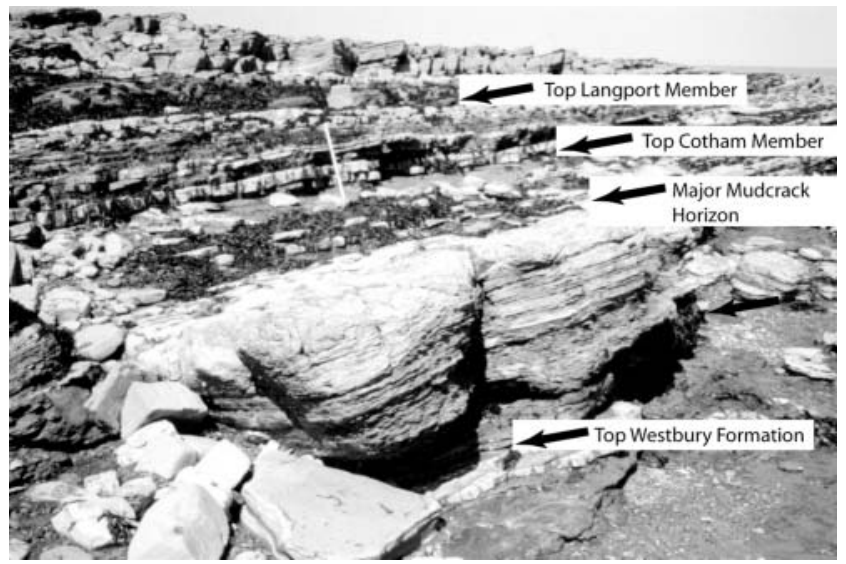

Fig. 6. Field photograph of the upper Lilstock Formation at St Audrie's Bay, west Somerset, indicating the positions of the main lithostratigraphic boundaries. One-metre stick for scale. The 'deformed bed' forms the prominent ledge immediately below the mudcrack horizon.

The upper Cotham Member also comprises thinly interbedded mudstone, siltstone, and fine-grained calcareous sandstone. The dividing line between the lower and upper parts of the Cotham Member is an erosion surface characterized by desiccation cracks extending down as much as $90 \mathrm{~cm}$, a surface termed the 'intraRhaetic unconformity' by Ivimey-Cook (1974). Mayall (1983) postulated that an earthquake-associated uplift of $c .2 \mathrm{~m}$ could account for both the deformed strata in the lower Cotham Member and the overlying mud-cracked erosion surface, although it is clear from the succession in Somerset that formation of the mudcracks post-dated formation of the deformed bed (Fig. 7a). The fill of the mudcracks is unstratified and represents only a single generation, suggesting extremely brief desiccation immediately preceding renewed deposition.

Sedimentary structures in the upper Cotham Member include wave-ripples with a variety of amplitudes and wavelengths, some flat-topped, and these are evidence of water depths of only a few centimetres (Fig. 7c; Mayall 1983). Also noteworthy in the upper Cotham Member is the common occurrence of radial calcite ooids in the sandy limestone beds, including the crack fills that penetrate through the deformed bed of the lower Cotham Member (Fig. 7b). Radial calcite ooids are typical of marine environments during certain periods of the Phanerozoic and the upper Cotham Member calcite ooids are noteworthy because the $\mathrm{Tr}-\mathrm{J}$ boundary corresponds approximately to a time of transition from aragonite to calcite seas (Sandberg 1983). In this respect the seawater chemistry during deposition of the Cotham Member shows more in common with typical Jurassic conditions than it does with Triassic.

The upper Cotham Member at St Audrie's Bay contains no bivalves. Ostracodes are present in the Cotham Member and generally represent environments ranging from marine (Bairdia, Ogmoconchella) to non-marine (Darwinula) (Boomer et al. 1999; R. J. Porter, pers. comm.). A biohermal limestone known as the Cotham Marble is a prominent marker at or near the top of the Cotham Member, particularly in the Bristol area. The limestone has an algal stromatolitic component (Hamilton, 1961) but is also made up from the problematic tubular organism Microtubus communis Flügel 1964 (see Mayall \& Wright 1981; Wright \& Mayall 1981).

The lower Cotham Member is a shallowing upward succession, capped by a surface characterized by deep desiccation cracks that are an unusual signature of dramatic fall in relative sea level
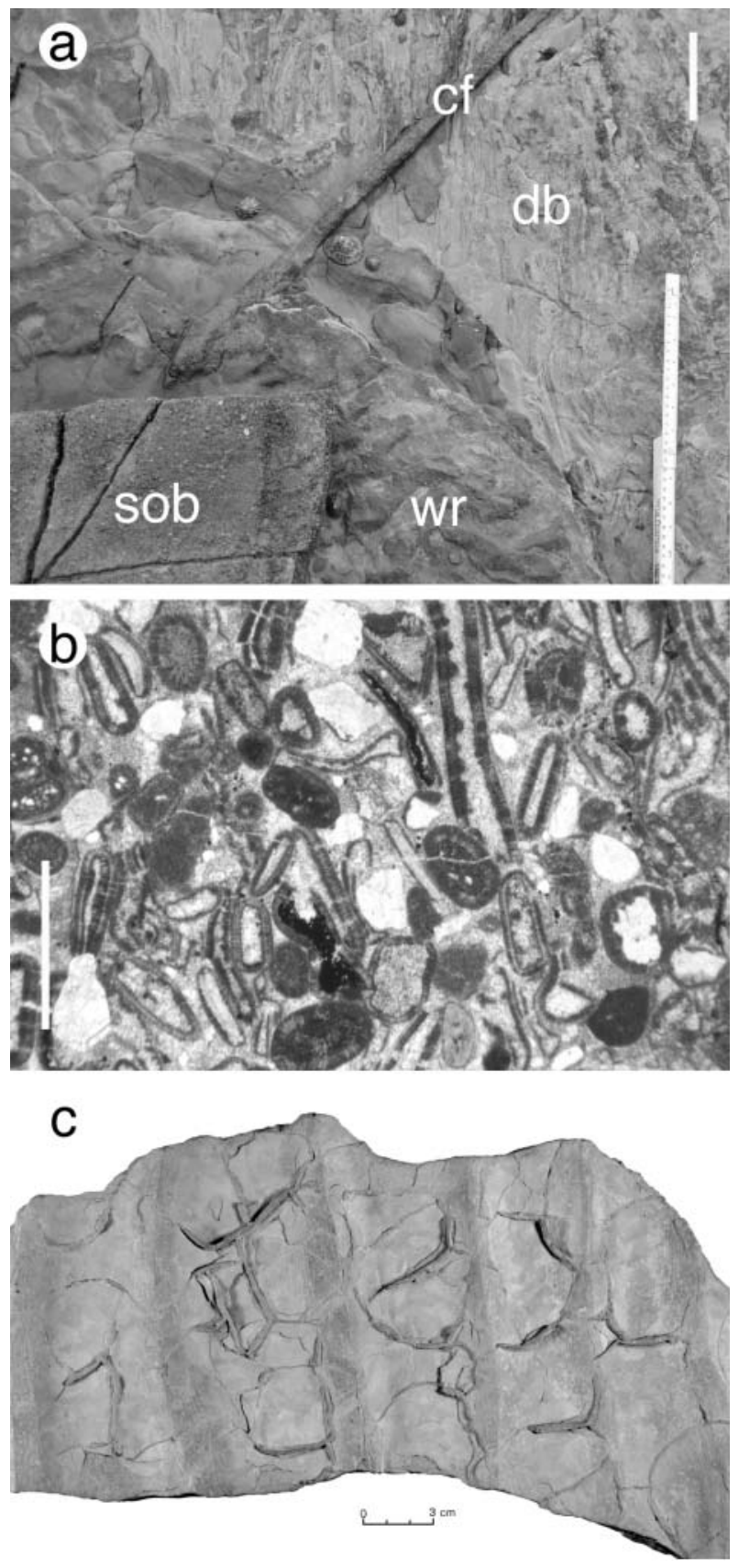

Fig. 7. Sedimentary features of the Cotham Member of the Lilstock Formation. (a) Plan view of cross-cutting relationships of key features within the Cotham Member, foreshore, St Audrie's Bay; db, deformed bed; cf, crack fill; wr, wave-rippled surface; sob, sandy oolitic bioclastic limestone bed. The deformed bed is overlain by a heterolith bed with small-scale wave-ripples. Both are cut by a sandy oolitic bioclastic limestone infilling the deep mudcracks. Scale bar represents $10 \mathrm{~cm}$. (b) Photomicrograph of sandy oobiosparite from crack fill of major desiccation-cracked horizon, St Audrie's Bay. Scale bar represents $1 \mathrm{~mm}$. (c) Symmetrical, flat-topped ripple marks and desiccation cracks, loose block but unambiguously derived from the upper Cotham Member, Lavernock. Scale bar represents $3 \mathrm{~cm}$.

(Fig. 4). The upper Cotham Member represents a coastal environment generated during a subsequent relative sea-level rise. The initial negative carbon-isotope excursion present in bulk organic matter analyses from St Audrie's Bay (Fig. 4) is 
identified as the same excursion occurring in candidate $\mathrm{Tr}-\mathrm{J}$ boundary strata in Pacific and Tethyan marine sections (Ward et al. 2001; Pálfy et al. 2001; Hesselbo et al. 2002; Geux et al. 2003). The start of the excursion in the St Audrie's Bay section is between 10 and $30 \mathrm{~cm}$ above the desiccation-cracked erosion surface, indicating that the isotopic excursion occurred some time after formation of that surface and during the early stages of the subsequent relative sea-level rise. Recent further carbonisotope analyses show that the carbon-isotope excursion is reproducible at Lavernock, and at Stowey Quarry, where it peaks at the level of the Cotham Marble (R. J. Porter \& S. P. Hesselbo, unpubl. data).

Langport Member. The upper member of the Lilstock Formation, the Langport Member, is of Rhaetian or Hettangian age depending on boundary definition. The unit consists of limestone or calcareous mudstone and was deposited in a fully marine environment (Richardson 1911; Hallam 1960a; Swift 1995). The junction with the underlying Cotham Member is sharp but conformable. Typically the limestones of the Langport Member are pure, micritic and pale grey; where this lithology is preeminent the unit has been referred to as the White Lias (a term used by William Smith in his table of strata dating from 1799). Although now micritic, the 'White Lias' facies of the Langport Member commonly displays small-scale swaley and hummocky cross-stratification (e.g. at Stowey Quarry in North Somerset and near Lyme Regis, Devon, Figs. 5 and 8a). Over much of the study area, the succession must therefore have originally been deposited as a grainstone, of coarse silt or fine sand size, presumably peloidal and subsequently recrystallized. Argillaceous and nodular limestone also occurs in the Langport Member. It is noteworthy that Simms (2003, fig. 1) described hummocky cross-stratified and wave-rippled sandstones from Northern Ireland at a stratigraphic position equivalent to the Langport Member. Simms (2003) interpreted these strata as a tsunamite, but their stratigraphic context, and facies similar to some top Langport Member limestones, indicates a storm-dominated siliciclastic shoreface setting as a viable alternative.

In west Somerset and south Wales, where the Langport Member is relatively thin, impure limestone and calcareous mudstone predominate (Figs. 4 and 5; Richardson 1911;

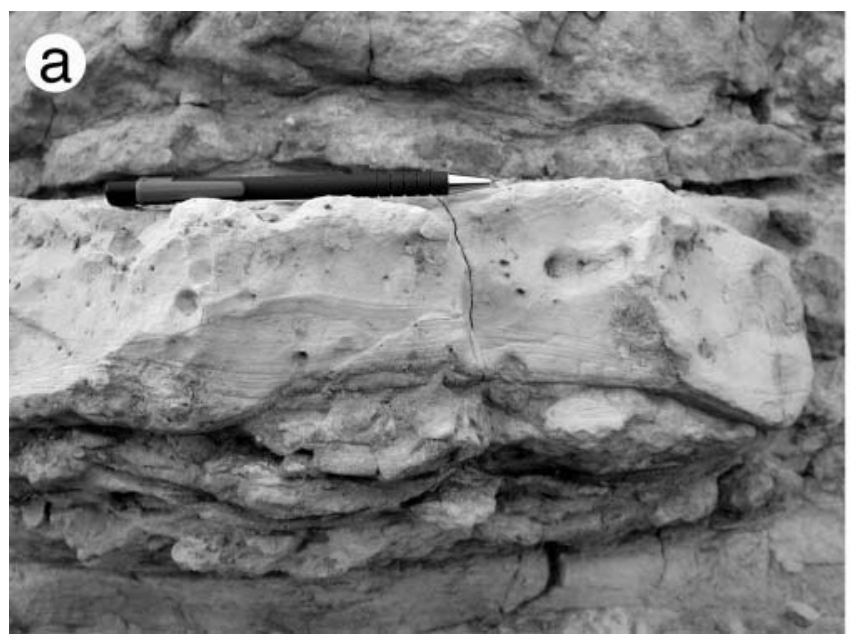

Whittaker 1978; Whittaker \& Green 1983). The bioturbated calcareous mudstone strata that form the top c. $2 \mathrm{~m}$ of the Langport Member at Lavernock, south Wales, were termed Watchet Beds by Richardson (1905). The appropriateness of this name has been questioned, mainly because the same lithology is present only as a very much thinner stratum $(c .30 \mathrm{~cm})$ around Watchet (Somerset) itself (Whittaker 1978). The lithostratigraphic usage, and supposed position of the $\mathrm{Tr}-\mathrm{J}$ boundary, is further confused because the level identified by Hallam (1995, fig. 2) as the top of his Watchet 'Member', and proposed as the $\mathrm{Tr}-\mathrm{J}$ boundary, is actually the base of the Watchet Beds as used by Richardson (1911) (compare Fig. 4, this study). Richardson (1911, p. 21) described the Watchet Beds at St Audrie's Bay as principally 'Shales, greyish, thinly laminated', whereas the graphic log in Hallam (1995), which is based upon field observations by P. B. Wignall, identified the Watchet 'Member' as interbedded marls and limestone. It should be noted that the lithological succession in Hallam's figure can easily be matched in detail to the bed-by-bed succession given by Richardson and to our own observations (Fig. 4): it is the lithostratigraphic boundaries that have been significantly misapplied. The position of Hallam's proposed Tr-J boundary shown in our Figs. 3 and 4 is taken directly from the position indicated in his graphic log (Hallam 1995, fig. 2).

Over much of SW Britain the upper bed of the Langport Member is commonly penetrated by Diplocraterion (Fig. 8b). In addition, the top surface of the Langport Member is reported to have a 'curiously marked upper surface resembling dried mud cracked by the sun' (Arkell 1933, p. 106). These markings have led to the bed being called the 'Sun Bed' but, as Arkell (1933, p. 106) pointed out, 'the origins of these cracks is by no means certainly known'. Subsequent frequent mention of desiccation cracks on this surface (e.g. Swift 1995) has never been supported by convincing illustration. Borings and fossils of encrusting organisms are also reported from this surface (and other surfaces within the upper Langport Member), indicating development of marine hardgrounds (e.g. Wignall 2001).

Considerable downslope sediment transport is indicated by numerous physical sedimentary features in the Langport Member in Devon (Hallam 1960a; Hesselbo \& Jenkyns 1995; Wignall 2001). These comprise a slump-folded bed (Fig. 9a; fold axis

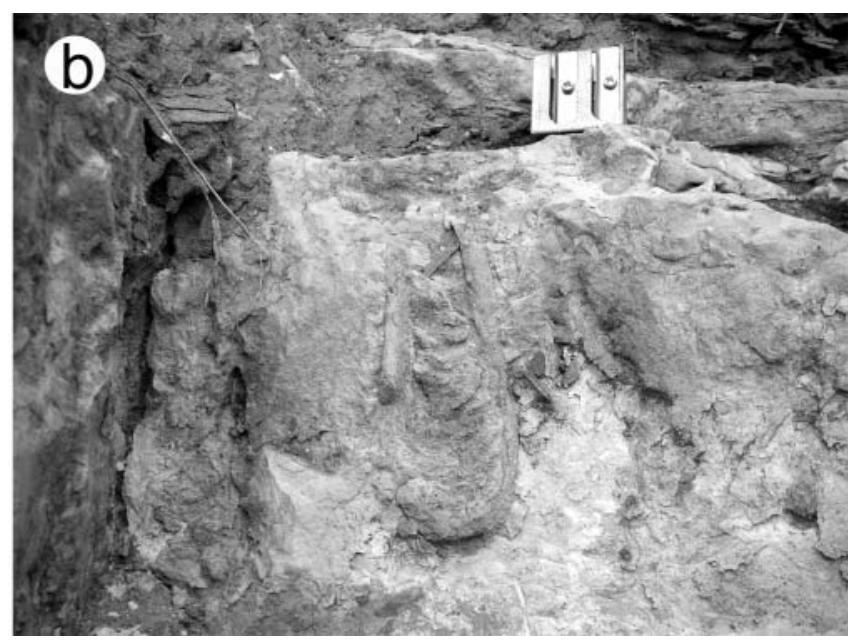

Fig. 8. Non-conglomeratic Langport Member. (a) Hummocky and swaley cross-stratification, Langport Member, Pinhay Bay, (near Lyme Regis), Devon. Length of pen is $14 \mathrm{~cm}$. (b) Diplocraterion from the Sun Bed, Pinhay Bay, (near Lyme Regis), Devon. Width of pencil sharpener is $2.5 \mathrm{~cm}$. 
oriented north-south) and a variety of debrite beds containing micritic limestone pebbles floating in a micritic limestone matrix (Fig. 9b). Broad erosional surfaces commonly form the bases of these latter beds and, in the lower parts of the exposed section define debris-flow-filled channels oriented north-south (Fig. 9c). Reworked pebbles and boulders of highly fossiliferous penecontemporaneous limestone are commonly included in the thinner debrites (Fig. 9d). Variably discontinuous seams of darker coloured limestone (Fig. 9b) form wavy horizontal and subhorizontal laminae within the debrite beds; these are locally clearly folded (Fig. 9e) and must have been produced whilst the sediment was soft, by processes of internal deformation during the debris flow event. Load structures occur at amalgamation surfaces between several debrites (Fig. 9f).

The occurrence of erosional bases and the existence of draped sediment over the common rafted boulders forming irregular tops of the conglomerate beds (Fig. 9g) point to deposition predominantly by gravity-driven flows occurring in discrete events. The slump and debris flow units in the Langport Member thus contrast with the otherwise similar 'deformed bed' in the lower Cotham Member in which lateral transition can be traced from deformed to undeformed strata, both at the top and the base of the bed.

In view of the significance for sea-level change attached by some workers to features of the conglomeratic facies at the top of the Langport Member at Pinhay Bay, Devon (section 2 of Wignall 2001) we include here an extended description and interpretation. The upper $c .80 \mathrm{~cm}$ of the Langport Member here comprises up to four partly amalgamated conglomeratic limestone beds, labelled 1-4 in Figs. 9h and 10. These beds can be distinguished by clast size and orientation, matrix content and composition. Additionally, the upper conglomerate overlies a discontinuous laminated shale. The lowest conglomerate is mainly clast-supported, with the larger clasts dominantly angular, elongate, brick-shaped and mainly subhorizontally oriented. Interstices are filled with poorly sorted pebble-sized clasts and the matrix content is rather low. One large clast is tilted and its lower edge is pressed down in the underlying bed (Fig. 9h), indicating that this was not fully cemented at the time of deposition of the conglomerate. The bed is non-graded and the clasts do not show any imbrication; the only type of organization is thus represented by the subhorizontal fabric. Deposition is interpreted to be from a low-volume sediment gravity flow in which the clasts were supported by buoyancy as indicated by the poor sorting and low matrix content (see Rodine \& Johnson 1976). Matrix viscosity thus played a rather minor role as a clast-supporting factor. The dense packing and relatively uniform appearance of the large angular clasts suggest that transport distance was short and that deposition took place by frictional freezing of a clast-rich debris flow.

Above this basal conglomerate, bed 2 (Figs. 9h and 10) is a poorly sorted pebble conglomerate with a few cobble-sized clasts. It is up to $30 \mathrm{~cm}$ thick and the upper boundary is highly irregular, whereas the base is an indistinct amalgamation surface. The bed wedges out laterally to the west and also thins to the eastern end of the exposure. It is clast-supported, and the poorly sorted clasts are very densely packed. The matrix content is low but weathering suggests that it has a higher content of clay than bed 1 . The clasts are subangular to subrounded and their shapes are more varied than in bed 1 . The clast-fabric is random but several clasts are vertically oriented. Deposition was from a clast-rich debris flow and the clasts were supported by buoyancy and matrix viscosity as indicated by the presence of vertical clasts. The irregular upper surface is partly of primary depositional origin, indicating rapid frictional freezing with possible development of pressure ridges. This is shown by the draping nature of the overlying thin laminated shale, which is up to about $3 \mathrm{~cm}$ thick. The shale is somewhat discontinuous as parts of it have been eroded or sheared by the overlying conglomerates of beds $3-4$. Bed 3 is a pebble conglomerate that wedges out towards the east from a thickness of $50 \mathrm{~cm}$. It overlies bed 2 directly and the thin shale has been removed by erosion during transport of the parent debris flow.

The discontinuous clay bed is overlain by the top conglomerate, bed 4. Small slabs of shale are incorporated at the base of bed 4 , which is a matrix-rich fine-pebble conglomerate. Where the shale is absent, the base of bed 4 is an amalgamation surface. Bed 4 is up to $c$. $20 \mathrm{~cm}$ thick and wedges out to the west. It shows coarse-tail grading of the lower more clast-rich part, whereas the upper part is a pebbly mudstone with scattered very fine pebbles. The top of the bed is sharp and only slightly undulating. Deposition is interpreted to be from a viscous debris flow where some clast segregation had taken place during transport as indicated by the coarse-tail grading.

The interpretation of the upper part of the Langport Member at Pinhay Bay given here contrasts with that of Wignall (2001), who suggested that the thin shale beds were horizontal shalefilled 'fissures' formed by freshwater dissolutional enlargement of small-scale listric faults. The karst interpretation may be criticized from the viewpoint of lack of modern morphological analogues and, additionally, the shale infilling the fissures is finely laminated and was deformed whilst in a soft state, both characteristics incompatible with passive infilling of dissolutional fissures in hard limestone. Furthermore, the shale occurs between conglomerate beds with contrasting lithological characteristics, an unlikely relationship if simply of dissolutional origin. The top Langport Member succession can be interpreted simply as a succession of small-volume debrites separated by amalgamation surfaces or a discontinuous shale bed.

The fauna of the Langport Member includes bivalves, gastropods, corals, echinoderms and rare conodonts, but there are no brachiopods, cephalopods or sponges, and the only arthropods reported are ostracodes (summarized by Swift 1999). This has generally been interpreted as reflection of abnormal and varying

Fig. 9. Langport Member, slope-related facies, Pinhay Bay, (near Lyme Regis), Devon. (a) Slump bed. The soft-sediment fold is overturned and has a fold axis with a north-south orientation. One-metre stick for scale. (b) Detail of matrix-supported small-pebble conglomerate showing weakly defined and discontinuous, roughly bed-parallel seams of dark micrite, interpreted as resulting from soft-sediment shear of primary inhomogeneities. Scale bar represents $5 \mathrm{~cm}$. (c) Scoured bases to matrix-supported small-pebble conglomerate beds. Scale bar is $1 \mathrm{~m}$. (d) Fossiliferous biomicrite lithoclast at base of massive pebbly micrite bed. Scale bar represents $1 \mathrm{~cm}$. (e) Slightly overturned folds affecting discontinuous seams interpreted as resulting from softsediment shear (compare (b)). Scale bar represents $20 \mathrm{~cm}$. (f) Amalgamation surface (arrowed) between separate matrix-supported small-pebble conglomerate beds showing load structures. Scale bar represents $10 \mathrm{~cm}$. (g) Rafted composite boulder ( $\mathrm{rb}$ ) of clast-supported conglomerate on top of clastrich conglomerate showing drape of overlying bed on uneven topography. Scale bar represents $10 \mathrm{~cm}$. (h) Detail of clast-rich conglomerate forming beds 1 and 2, and overlying matrix-rich conglomerate of bed 4 as illustrated in Figure 10. Scale bar represents $50 \mathrm{~cm}$. 

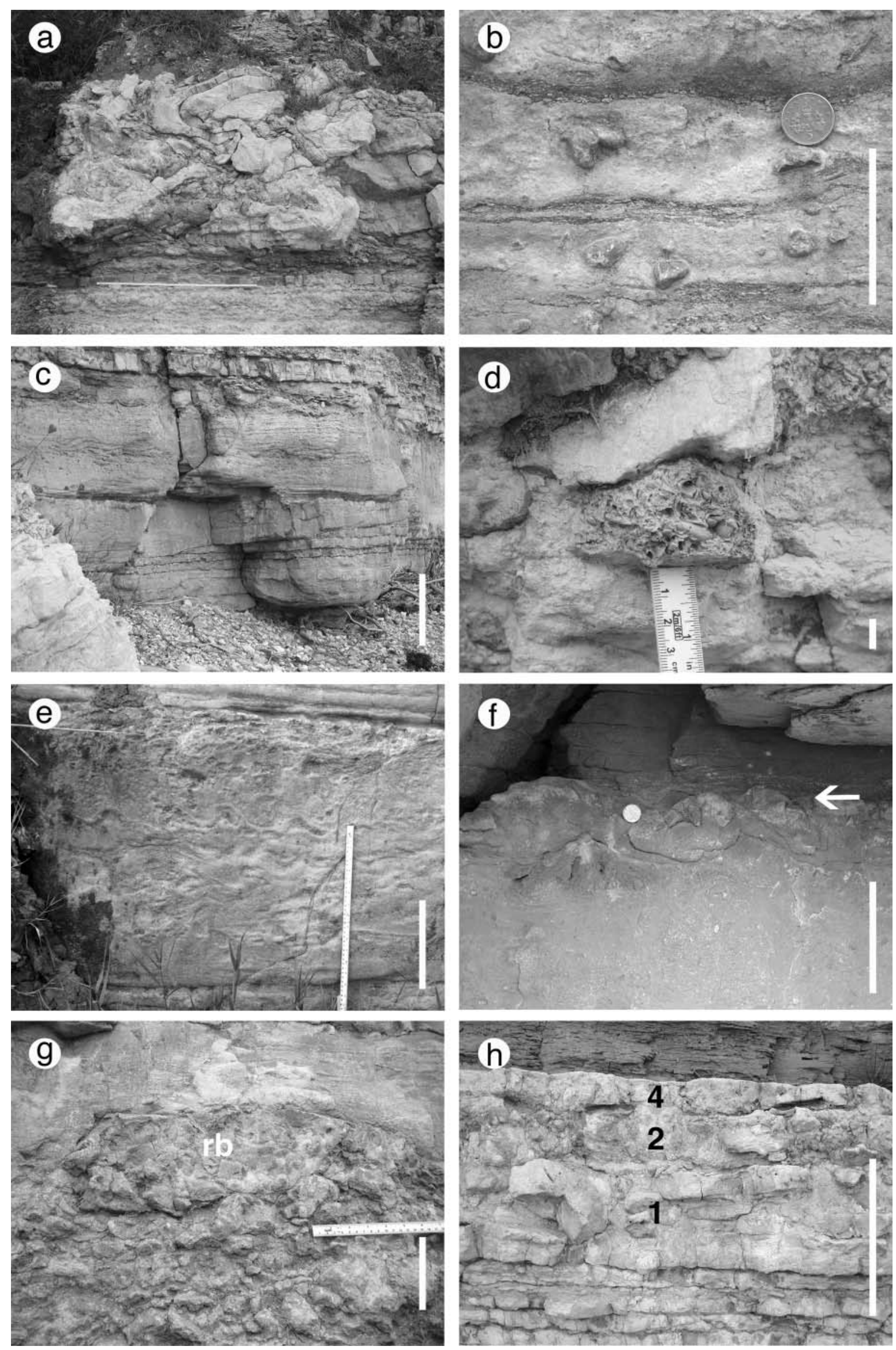


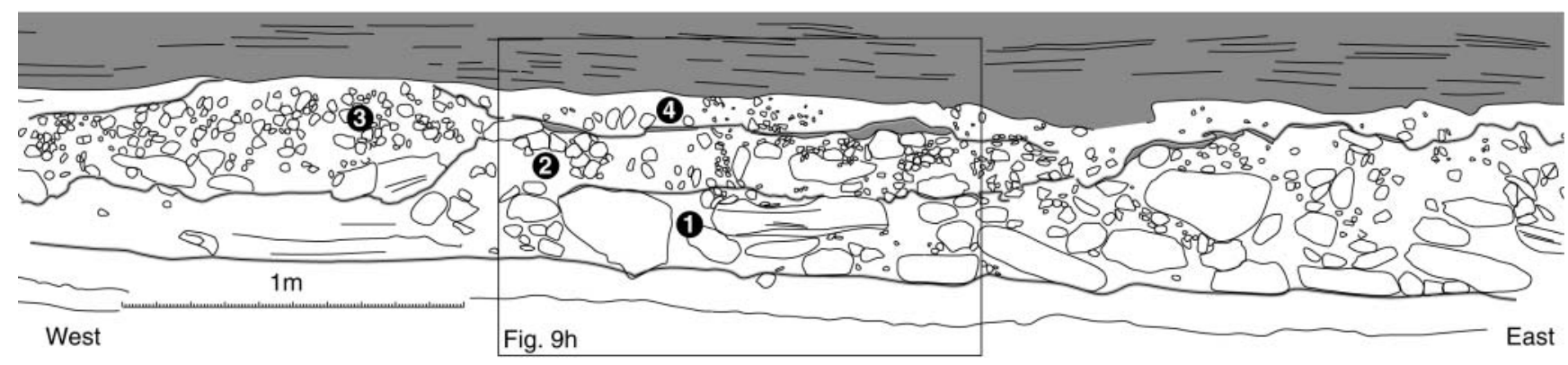

Fig. 10. Line drawing based on photomontage (taken on 28 October 2003) of upper c. $1 \mathrm{~m}$ of Langport member, Pinhay Bay, Devon (section 2 of Wignall 2001). All pebbles visible in the montage (compare Fig. 9h) have been included in the line drawing. Bed 2 is separated from bed 4 by a thin discontinuous laminated shale that was deformed and partly eroded during deposition of bed 4 .

salinities (Hallam \& El Shaarawy 1982), but debris from stenohaline echinoids is relatively common (Swift 1999, p. 163) and corals also occur, so it may be that the faunal content represents substrate rather than salinity control. Hallam (1960a) compared the Langport Member facies to the 'shelf lagoons' west of Andros and Abaco islands in the Bahamas. He suggested similar depositional environments based on: (1) high strontium content of the Langport Member calcite, interpreted as inherited from an aragonite precursor; (2) occurrence of 'intraformational' conglomerate and hard clean micritic limestone, interpreted as a product of subaerial cementation and erosion; (3) corrugated surfaces interpreted as due to subaerial corrosion; (4) faunal similarities. High strontium content is now known to be a common feature in Upper Triassic strata in SW England, where the strontium is contained in celestite and is unrelated to an aragonite precursor (Hesselbo \& Jenkyns 1995; Wignall 2001). The conglomerate is here interpreted as an entirely submarine phenomenon, originating from transport and break-up of partially consolidated lime mud in debris flows, and 'corrugated' surfaces are identified as folded internal flow structures and amalgamation surfaces at the bases of individual debrites. Because of a lack of evidence for any kind of barrier facies and because of the wide lateral extent of the Langport Member, Wignall (2001, p. 356) rejected the 'lagoonal' interpretation, and suggested instead that deposition occurred in 'a broad shallow seaway of slightly abnormal salinity with dampened tidal activity and perhaps limited wave fetch', these last two factors presumably inferred on the basis of the predominantly micritic nature of the limestones.

On the basis of the fauna, localized evidence of storm deposition (e.g. at Stowey), and ubiquitous evidence of gravitydriven transport processes (e.g. at Lyme Regis) we suggest here that the depositional environment of the Langport Member was a carbonate ramp that, at least locally, developed a submarine slope steep enough to initiate gravity flows. There are two possibilities for slope generation: (1) depositional processes operating as the ramp developed (e.g. Wright \& Burchette 1996); or (2) tectonic tilt, such as might be expected on the hanging wall of a synsedimentary fault (e.g. the offshore extension of the Eype Mouth fault (Jenkyns \& Senior 1991; Hesselbo \& Jenkyns 1995)). In the English Midlands there is good evidence from geophysical log correlations to suggest that the Langport Member sediments underwent tectonic tilting prior to deposition of the overlying Blue Lias mudstones (Donovan et al. 1979; Horton et al. 1987). Down-slope sediment transport would be expected on relatively steep parts of a depositional ramp or a hanging-wall ramp, whether triggered by seismic events or not.
The Cotham Member-Langport Member junction is interpreted to represent a flooding surface generated as relative sealevel rise outpaced clastic sediment supply. In some areas (e.g. St Audrie's Bay and Lavernock) the basin was clearly sediment starved, and only reduced sedimentation occurred during this deepening phase, resulting in a very thin Langport Member. Presumably these areas represent the more distal parts of any carbonate ramp system. The 'Sun Bed', forming the top surface of the Langport Member, is interpreted herein as a regional drowning surface produced as rising sea level overcame the productive capabilities of the carbonate system. Drowning may occur on relatively unproductive ramps simply through rapidly increasing accommodation creation in proximal locations, or because of suppression of carbonate production through increased clastic supply, nutrient flux, or high temperature (e.g. Weissert et al. 1998; Jenkyns \& Wilson 1999). Subaerial exposure and attendant meteoric modification of the upper surface of the Langport Member cannot be ruled out, but there is no positive evidence, either in the form of clear karstic dissolutional structures, or by the presence of non-marine cements or sediments, and thus extensive exposure has to be regarded as unlikely at this time.

\section{Lias Group}

Blue Lias Formation. The typical Blue Lias, at the base of the Lias Group, comprises rhythmic interbeds of laminated organicrich shale, pale and dark marl, and limestone. Primary differences in ichnofabrics and fossil content between beds of contrasting lithology have survived the clear diagenetic redistribution of carbonate within the succession that is evident in the external morphology of concretionary limestones (Hallam 1960b, 1964; Weedon 1985). The transition from the Langport Member to the Blue Lias can be either abrupt, as is the case in more marginal settings around the Mendips, or gradational, as is the case around Lyme Regis, where the lower few limestone beds of the Blue Lias are lithologically very similar to the Langport Member (Hesselbo \& Jenkyns 1995). Despite a careful search and detailed logging (Fig. 4), we have not been able to identify the conglomerate reported at the Langport Member-Blue Lias junction at St Audrie's Bay, Somerset, by Hallam (1990). The observation may be based on the mistaken identification of some other feature of this horizon such as the development of carbonate nodules.

Bottom-water oxygenation must have varied significantly through deposition of the Blue Lias, as is evident now through the variations in burrowing intensity and benthic fossil diversity. 
In general, the more carbonate-rich beds reflect well-oxygenated conditions, whereas the organic-rich facies represent anoxic conditions at the sea floor. Weedon et al. (1999) interpreted these regular cycles through the Blue Lias at Lyme Regis as being due to obliquity forcing, i.e. c. $40 \mathrm{ka}$, whereas the same thickness cycles from the upper part of the Blue Lias were interpreted by Waterhouse (1999) as eccentricity related, i.e. c. $100 \mathrm{ka}$. The contrast in interpretation is unresolved but has obvious implications for the estimated minimum duration of the Hettangian Stage.

The fauna of the Blue Lias is marine, but there is a notable change in the fauna upwards from the base of the formation. The lowest few metres, the so-called 'Pre-Planorbis Beds', lack ammonite fossils and are characterized by an abundance of the oyster Liostrea hisingeri (Nilsson), with the mussel Modiolus minimus (J. Sowerby) also being common. The precise environmental controls that brought about the change from bivalvedominated assemblages to assemblages in which ammonites are dominant are obscure, but possibly there were no ammonites existing at that time that were adapted to such shallow-marine conditions.

The occurrence of millimetre-scale lamination and abundant pyrite framboids in the many shale beds of the Blue Lias, including those at the base of the 'Pre-Planorbis Beds', indicates poorly oxygenated to euxinic conditions and implies water depths sufficient to prevent wave-mixing of bottom waters with welloxygenated surface waters (Hallam 1997; Wignall 2001). This depth is estimated to be at least a few tens of metres (Wignall 2001).

\section{Placement of the $\mathrm{Tr}-\mathrm{J}$ boundary in the SW British succession}

Definition of the $\mathrm{Tr}-\mathrm{J}$ boundary has not yet been formally agreed. In this section we outline the levels at which various workers have suggested placement of the base of the Hettangian Stage and thus the Tr-J boundary in SW Britain. The choices of boundary level reflect philosophical and methodological preferences of different workers. The extreme end-members are identification of a horizon that represents a perceived mass extinction event, versus a biostratigraphically correlatable horizon in an uninterrupted succession closely post-dating any mass extinction.

Discounting earlier suggestions that the Rhaetian Stage should be included within the Jurassic (Arkell 1933), the lowest level that has been suggested as marking the Triassic-Jurassic boundary in SW Britain is within the Cotham Member (Fig. 4), lying at the junction between the Rhaetipollis and Heliosporites miospore zones (Orbell 1973, p. 33). Some support for a return to this boundary definition comes from recent work on carbonisotope values of terrestrial and marine organic matter in the St Audrie's Bay section (Fig. 4), together with comparisons with isotope data from sections elsewhere (Hesselbo et al. 2002).

On the basis of non-ammonite faunas (mostly bivalves), abrupt lithological change, and perceived lateral facies equivalence of the Langport Member and basal Blue Lias strata, it has been suggested that the base of the Langport Member should be regarded as marking the Triassic-Jurassic boundary (Poole 1979, $1980,1991)$. Some of the faunal evidence used by Poole has been questioned, principally the claim that a distinct change in bivalve faunas occurs between the top of the Westbury Formation and the base of the Langport Member (Ivimey-Cook et al. 1980), but a full review of the bivalve faunas has never been published.

The base of the Blue Lias in the Watchet area (as marked by the 'Paper Shale' of Richardson, 1911) is another horizon that has been considered to mark the Triassic-Jurassic boundary (George et al. 1969). The basis for this suggestion is that this horizon could be defined as representing the base of the 'Planorbis Zone' (in the sense of a chronozone or so-called standard zone) despite the fact that it could not be discriminated locally by palaeontological means.

Hallam $(1990,1995)$ effectively made a similar suggestion to George et al. (1969) by proposing that the base of the Blue Lias marked the $\mathrm{Tr}-\mathrm{J}$ boundary in SW England. He argued that the $\mathrm{Tr}-\mathrm{J}$ boundary should be placed within a unit known as the Grenzmergel in the Austrian Alps on the basis of stratigraphic distributions of a number of faunal and floral groups, particularly bivalves, and proposed that the top of the Langport Member could be correlated to the base of the Grenzmergel by fossil content and interpreted sea-level change. Hallam (1991) explicitly stated that changes in bivalve assemblages marked a mass extinction. In counterargument, the accuracy of Hallam's reported fossil stratigraphic patterns and identifications has been challenged (Cope 1991a, b). A further problem with Hallam's interpretation of the $\mathrm{Tr}-\mathrm{J}$ boundary concerns his misapplication of the lithostratigraphic scheme in the St Audrie's Bay section as discussed above.

A more strictly biostratigraphical base to the 'Planorbis Zone' (i.e. Psiloceras planorbis ammonite zone) was suggested to be the level of first occurrence of Psiloceras planorbis (IvimeyCook et al. 1980; Torrens \& Getty 1980), and this has subsequently stood as the principal proposed boundary marker for the St Audrie's Bay candidate Global Stratotype Section and Point (Cope 1991a, b; Warrington et al. 1994; Warrington \& Ivimey-Cook 1995). A significant problem with this proposal is that it is now recognized that other species of Psiloceras appear below P. planorbis, and it is doubtful whether any first appearance of Psiloceras was globally synchronous (e.g. Hodges 1994; Bloos \& Page 2000; Hesselbo et al. 2002; Robinson 2002).

\section{The $\mathbf{T r}-\mathbf{J}$ boundary and mass extinction}

The Triassic-Jurassic boundary has been the focus of considerable recent attention because it represents the least well understood of all the major Phanerozoic mass extinctions. To date, there is strong direct evidence for major extraterrestrial impacts only for the Late Triassic rather than at the $\mathrm{Tr}-\mathrm{J}$ boundary (Hodych \& Dunning 1992; Walkden et al. 2002; compare Olsen et al. 2002; Simms 2003), and the most likely principal forcing factor for environmental change is plume-related flood-basalt volcanism of the Central Atlantic Magmatic Province (McHone 1996, 2000; Marzoli et al. 1999; Hames et al. 2000; Pálfy et al. 2001; Hesselbo et al. 2002). That volcanism theoretically had the capacity to create major environmental changes through regional sea-level change (e.g. Hallam \& Wignall 1999) and volcanic gases (McElwain et al. 1999; Hesselbo et al. 2002). Methanehydrate dissociation is another factor that has been suggested as potentially significant at the $\mathrm{Tr}-\mathrm{J}$ boundary and certainly this mechanism has the potential to explain the negative carbonisotope excursion (Pálfy et al. 2001; Beerling \& Berner 2002).

An important outcome of the present reassessment of the evidence is that all the horizons in the SW British succession proposed as possible boundary markers occur during a phase of sustained and substantial relative sea-level rise, albeit after an undoubted phase of short-lived relative sea-level fall represented by the lower Cotham Member. Can any of these horizons be interpreted convincingly as representing times of accelerated extinction? 
The most recent review of extinction chronology across the Tr-J boundary is that of Hallam (2002), who stressed the inadequacy of the currently available data but concluded that a major $\operatorname{Tr}-\mathrm{J}$ boundary catastrophic extinction was less likely than a drawn-out, stepped or gradual Late Triassic extinction. Of the possible $\operatorname{Tr}-\mathrm{J}$ boundary horizons considered herein, only the lowest horizon (the Rhaetipollis-Heliosporites palynozone boundary within the Cotham Member) exhibits any direct evidence of biotic changes: a sharply defined decline in certain pollen species, their replacement by other pollen and appearance of relatively abundant trilete spores (Orbell 1973).

Comparisons can be made with successions in the Newark Basin of eastern North America, where the $\mathrm{Tr}-\mathrm{J}$ boundary is suggested to coincide with a horizon across which there are sharp and distinctive changes in vertebrate footprint assemblages. There also, the boundary is marked by a high abundance of trilete spores (i.e. a 'fern spike'; Fowell et al. 1994; Olsen et al. 2002). Above this level, palynological assemblages are dominated by circumpolles pollen of the taxon Classopollis. The palynological data from SW Britain indicate that circumpolles pollen is the dominant component of the Blue Lias palynological assemblages, but is also present in very high abundances in older strata, in the Blue Anchor Formation and basal Westbury Formation (Fig. 11; Wall 1965; Orbell 1973; Warrington \& Whittaker 1984; Warrington et al. 1995). There is additionally a small relative peak in trilete spore and circumpolles pollen abundances within the Cotham Member that occurs synchronously with the initial negative carbon-isotope excursion (Fig. 10; Orbell 1973; Hesselbo et al. 2002; Robinson 2002). Thus, on the basis of combined spore and pollen abundance patterns, a case can be made for correlation between the RhaetipollisHeliosporites zonal boundary in the Cotham Member of SW England and the suggested $\mathrm{Tr}-\mathrm{J}$ boundary in eastern North America. In contrast, such a correlation is not supported by the available palaeomagnetic data (Hounslow et al. 2001, in press.); specifically, a short reversed magnetozone occurs in the base of the Blue Lias at St Audrie's Bay (Fig. 4) that is correlated with a reversed magnetozone below the supposed $\mathrm{Tr}-\mathrm{J}$ boundary in the Newark Basin. Current sample resolution of the magnetostratigraphy leaves open the option for further reversals to be discovered and alternative correlations to be suggested.

At St Audrie's Bay the Rhaetipollis-HeliosporitesZone boundary corresponds to the start of the so-called 'initial' negative carbon-isotope excursion, which persists to the lowest Langport Member (Fig. 4; Hesselbo et al. 2002). On the basis of palynology (Pedersen \& Lund 1980, p. 63) and carbon-isotope data (Hesselbo et al. 2002) it has also been suggested that the Rhaetipollis-Heliosporites Zone boundary in the Cotham Member correlates with a level in $\mathrm{Tr}-\mathrm{J}$ boundary successions of Jameson Land, East Greenland, where an important species-level macrofloral extinction event has been demonstrated (Harris 1937). If this level is subsequently shown to represent a more general $\mathrm{Tr}-\mathrm{J}$ mass extinction, then it follows that conodonts just survived the extinction event, unless, of course, the conodont occurrences in SW Britain are reworked (see Hallam 1991; Swift 1999).

The higher horizons suggested as marking the $\mathrm{Tr}-\mathrm{J}$ boundary in SW Britain are less persuasively interpreted as marking any kind of major faunal or floral change, but rather are interpreted here as the local record of faunal changes that had already taken place but could not be recorded in the SW British area until the depositional environment was appropriate. The correlation by Hallam (1990) of the top of the Langport Member with the base of the Grenzmergel in Austria is the basis for his suggestion that
Lavernock Point, South Wales

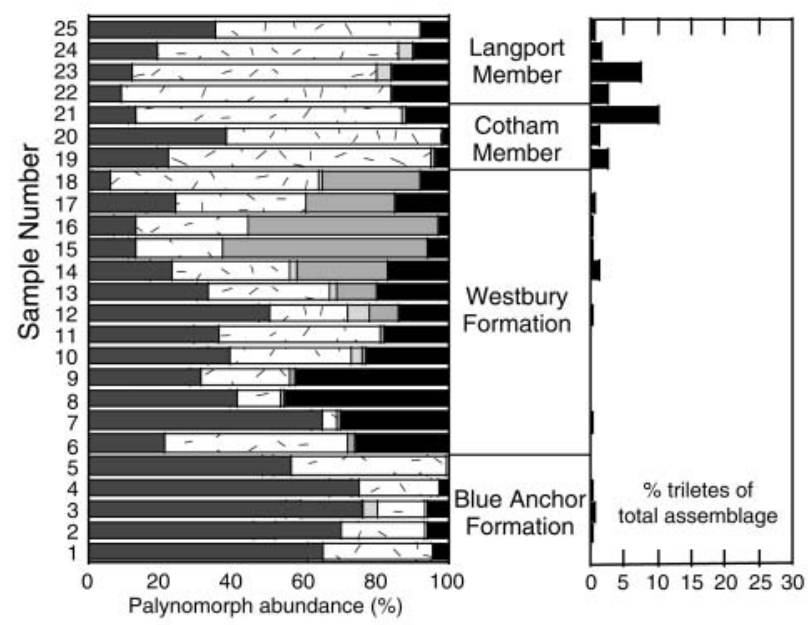

Upton Borehole, Oxfordshire

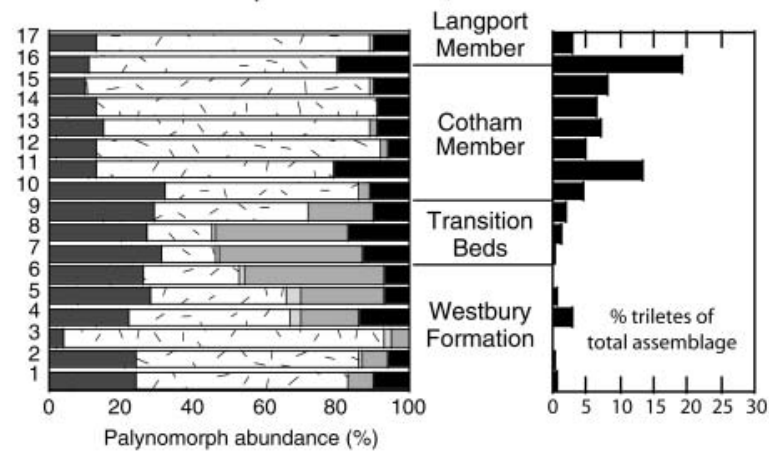

Fox Holes Borehole, Nottinghamshire
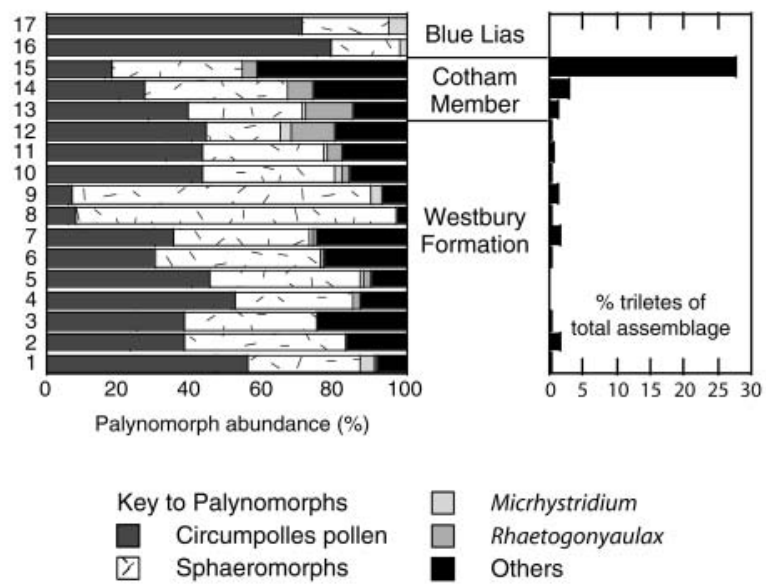

Fig. 11. Compilation of palynological data from Orbell (1973) for Lavernock Point (South Glamorgan), and from two locations in central England: Upton Borehole (Oxfordshire) and Fox Holes Borehole (Nottinghamshire). In the columns on the right are the abundances of trilete spores in each of Orbell's samples. Lithostratigraphy is the modern equivalent of names used by Orbell (1973). Circumpolles pollen includes taxa identified by Orbell as Classopollis, Corollina and Granuloperulatipollis.

this surface in SW England represents the principal time of extinction of bivalve faunas (Hallam 1991), but it may equally be argued that the Langport Member represents a palaeoenvironment in which the bivalve faunas that typify the Blue Lias could 


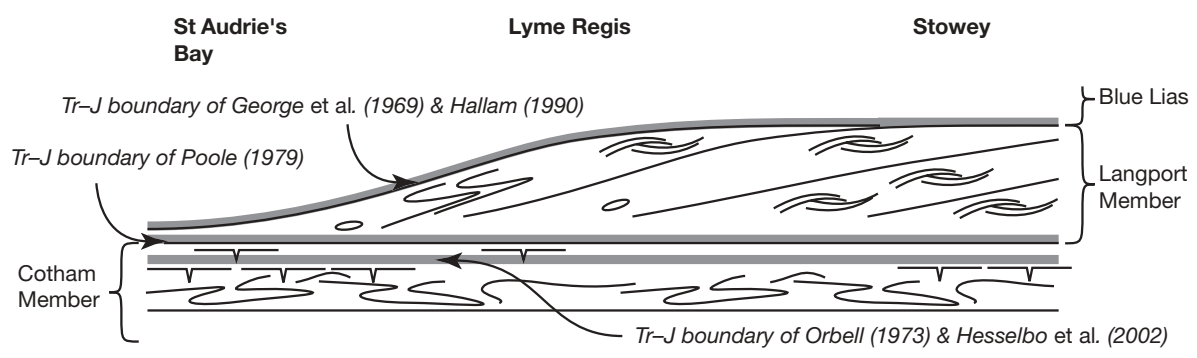

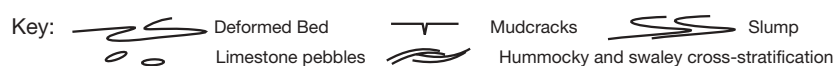

Fig. 12. Schematic illustration of proposed relationship between sedimentary facies and sea-level change across the TriassicJurassic boundary, SW Britain. The illustration depicts the time of drowning of the Langport Member carbonate ramp. not live. The suggestion made by Poole $(1979,1991)$ that the boundary be placed at the base of the Langport Member is different from Hallam's interpretation principally in that Poole considered the Langport Member to be a time-equivalent lateral facies variant of the lowest Blue Lias, and that the most significant faunal and lithological changes could be demonstrated as occurring between the Cotham Member and the Langport Member (e.g. in the Stowell Park Borehole: Melville 1956; Poole 1991). However, again, such faunal changes as did occur may have happened earlier but were not recorded in the local succession until the appropriate environment was established.

The uppermost horizon considered to represent the $\mathrm{Tr}-\mathrm{J}$ boundary, the lowest occurrence of the ammonite Psiloceras planorbis, has never been considered as representing a mass extinction event, but instead is interpreted by all workers as a more or less easily correlated bio-event developed in relatively stable, perhaps increasingly open marine, palaeoenvironmental conditions. Definition of the boundary at this level would fix it at a position that clearly post-dates any time of major environmental change.

\section{Summary and conclusions}

An interpretation of relative sea-level change in the southern UK area is presented that contrasts with that of previous workers in terms of the significance of specific surfaces and timing with respect to the Triassic-Jurassic boundary (Hallam 1988, 1995, 1997; Hallam \& Wignall 1999). However, the overall pattern of sea-level change is not dissimilar. An initial negative carbonisotope excursion occurred during the earliest phases of relative sea-level rise in SW Britain. Further recognition of this excursion in other areas of Europe where relative sea-level changes are unambiguous, such as southern Germany (Bloos 1990), should help to determine whether there was a pervasive regional relative sea-level control on stratigraphic patterns (see Hallam 1990; Hallam et al. 2000). The sea-level history across the $\operatorname{Tr}-\mathrm{J}$ boundary in SW Britain includes the following elements.

(1) An initial phase of relative sea-level rise culminated with widespread deposition of black shale in an offshore setting (lower and middle Westbury Formation).

(2) A slowing of relative sea-level rise, and subsequent sealevel fall, is indicated by a coarsening-upward shoreface succession sitting more or less abruptly on offshore deposits (upper Westbury Formation and lower Lilstock Formation (lower Cotham Member)).

(3) Sea-level fall and lowstand conditions are marked by a widespread surface within the Cotham Member that is characterized by uncommonly deep sand-filled cracks, probably of desiccation origin. The occurrence of a single surface of cracks containing a homogeneous fill, together with truncation of under- lying sedimentary structures, indicates a degree of erosion and then drying immediately prior to renewed flooding and subaqueous deposition.

(4) Subsequent sustained sea-level rise led to the development of an overall deepening-upward succession in west Somerset and south Wales, marked by development of mixed siliciclastic deposits and marine carbonates (upper Cotham Member), thin shoreface limestones (Langport Member) and offshore mudstones and limestones (Blue Lias Formation). A negative carbon-isotope excursion (the 'initial excursion') characterizes the earliest phase of this sea-level rise in SW Britain.

(5) In areas closest to regions of carbonate production, a storm-dominated carbonate ramp was formed during the middle stages of the relative sea-level rise. Either through depositional processes or through tectonic tilting, this ramp became sufficiently steep in places to generate ubiquitous gravity-flow deposits (e.g. the Langport Member in Devon).

(6) The top surface of the Langport Member (the 'Sun Bed') marks the final drowning of the carbonate ramp across the whole southern UK region. There is no firm evidence to support the interpretation that this surface was subaerially exposed. Exposure also seems particularly unlikely in the areas where the ramp was steep and the facies characterized by gravity-flow deposits.

Figure 12 summarizes schematically a possible arrangement of depositional facies at the time of ramp drowning, assuming a depositional rather than a tectonic ramp. The best candidate for a horizon that marks a ' $\mathrm{Tr}-\mathrm{J}$ boundary' mass-extinction event occurs in the upper Cotham Member, sediments laid down during the early stages of relative sea-level rise following a pronounced, probably short-lived, sea-level lowstand. However, mechanisms that link $\mathrm{Tr}-\mathrm{J}$ boundary extinctions directly to a sea-level lowstand on either a regional scale or a global scale are not supported by the currently available data.

We thank M. Becker for her help with fieldwork, and S. Wyatt, O. Green and S. Dolan for laboratory assistance. S.A.R. was funded whilst at Oxford by an NERC (UK) studentship (GT04/224/98/ES). F.S. is supported by the Danish Natural Science Research Council. This is a contribution to IGCP Project 458 (Triassic-Jurassic Boundary Events). We are grateful to the Royal Society, London, for a research grant to S.P.H. and for financial support for the IGCP 458 field workshop in SW England, 2001. We thank M. Hounslow, R. Twitchett and R. Porter for scientific discussion, and P. Wignall, C. McRoberts and J. Howell for constructive criticism during the review process.

\section{References}

Arkell, W.J. 1933. The Jurassic System in Great Britain. Clarendon Press. BeErling, D.J. \& Berner, R.A. 2002. Biogeochemical constraints on the Triassic-Jurassic boundary carbon cycle event. Global Biogeochemical Cycles, 16(3), 10.1029/2001GB001637. 
Benton, M.J. 1986. More than one event in the late Triassic mass extinction. Nature, 321, 857-861.

BLoos, G. 1990. Eustatic sea-level changes in the Upper Keuper and Lower Lias of central Europe. Cahiers de l'Université Catholique de Lyon, Série Sciences, 3, 5-16.

Bloos, G. \& PAge, K.N. 2000. The basal Jurassic ammonite succession in the North-West European province-review and new results. In: HALL, R.L. \& Sмith, P.L. (eds) Advances in Jurassic Research 2000. TransTech, Zürich, 2000, 27-40.

Boomer, I.D., Duffin, C.J. \& SwIFT, A. 1999. Arthropods 1: crustaceans. In: Swift, A. \& Martill, D.M. (eds) Fossils of the Rhaetian Penarth Group. The Palaeontological Association, 129-148.

Cope, J.C.W. 1991a. Discussion on correlation of the Triassic-Jurassic boundary in England and Austria. Journal of the Geological Society, London, 148, 420.

Cope, J.C.W. 1991b. Further discussion on correlation of the Triassic-Jurassic boundary in England and Austria. Journal of the Geological Society, London, 148, 943.

Donovan, D.T., Horton, A. \& Ivimey-Cook, H.C. 1979. The transgression of the Lower Lias over the northern flank of the London Platform. Journal of the Geological Society, London, 136, 165-173.

Duffin, C.J. 1980. The Upper Triassic section at Chilcompton, Somerset, with notes on the Rhaetic of the Mendips in general. Mercian Geologist, 7, 251-268.

Fowell, S.J., Cornet, B. \& Olsen, P.E. 1994. Geologically rapid Late Triassic extinctions: palynological evidence from the Newark Supergroup. In: KLEIN, G.D. (ed.) Pangea: Paleoclimate, Tectonics and Sedimentation During Accretion, Zenith, and Breakup of a Supercontinent. Geological Society of America, Special Papers, 332, 49-57.

FrancIS, E.H. 1959. The Rhaetic of the Bridgend District, Glamorganshire. Proceedings of the Geologists' Association, 70, 158-170.

George, T.N., Harland, W.B. \& Ager, D.V. et AL. 1969. Recommendations on stratigraphical usage. Proceedings of the Geological Society, London, 1656, $139-166$.

Geux, J., Bartolini, A., Atudorei, V. \& Taylor, D. 2003. Two negative $\delta^{13} \mathrm{C}$ excursions near the Triassic-Jurassic boundary in the New York Canyon area (Gabbs Valley Range, Nevada). Bulletin de Géologie, Lausanne, Numéro Spécial, 360, 1-4.

Hallam, A. 1960a. The White Lias of the Devon coast. Proceedings of the Geologists' Association, 71, 47-60.

Hallam, A. 1960 b. A sedimentary and faunal study of the Blue Lias of Dorset and Glamorgan. Philosophical Transactions of the Royal Society, London, Series $B, 243,1-44$.

Hallam, A. 1964. Origin of the limestone-shale rhythm in the Blue Lias of England: a composite theory. Journal of Geology, 72, 157-169.

Hallam, A. 1988. A re-evaluation of the Jurassic eustasy in the light of new data and the revised Exxon curve. In: Wilgus, C.K., Hastings, B.S., Kendall, G.St.C., Posamentier, H.W., Ross, C.A. \& van Wagoner, J.C. (eds) SeaLevel Changes: an Integrated Approach. Society of Economic Paleontologists and Mineralogists, Special Publications, 42, 71-108.

Hallam, A. 1990. Correlation of the Triassic-Jurassic boundary in England and Austria. Journal of the Geological Society, London, 147, 421-424.

Hallam, A. 1991. Reply to discussion on correlation of the Triassic-Jurassic boundary in England and Austria. Journal of the Geological Society, London, 148, 421.

Hallam, A. 1995. Oxygen-restricted facies of the basal Jurassic of North West Europe. Historical Biology, 10, 247-257.

Hallam, A. 1997. Estimates of the amount and rate of sea-level change across the Rhaetian-Hettangian and Pliensbachian-Toarcian boundaries (latest Triassic to early Jurassic). Journal of the Geological Society, London, 154, 773-779.

Hallam, A. 2002. How catastrophic was the end-Triassic mass extinction? Lethaia, 35, 147-157

Hallam, A. \& El ShaArawy, Z. 1982. Salinity reduction of the end-Triassic sea from the Alpine region into northwestern Europe. Lethaia, 15, 169-178.

Hallam, A. \& Goodfellow, W.D. 1990. Facies and geochemical evidence bearing on the end-Triassic disappearance of the Alpine reef ecosystem. Historical Biology, 4, 131-138.

Hallam, A. \& Wignall, P.B. 1997. Mass Extinctions and their Aftermath. Oxford University Press, Oxford.

Hallam, A. \& Wignall, P.B. 1999. Mass extinctions and sea-level changes. Earth-Science Reviews, 48, 217-250.

Hallam, A., Wignall, P.B., Yin, J. \& Riding, J.B. 2000. An investigation into possible facies changes across the Triassic-Jurassic boundary in southern Tibet. Sedimentary Geology, 137, 101-106.

Hames, W.E., Renne, P.R. \& Ruppel, C. 2000. New evidence for geologically instantaneous emplacement of earliest Jurassic Central Atlantic magmatic province basalts on the North American margin. Geology, 28, 859-862.

Hamilton, D. 1961. Algal growths in the Rhaetic Cotham Marble of southern England. Palaeontology, 4, 324-333.
Hamilton, D. 1977. Aust Cliff. In: Savage, R.J.G. (ed.) Geological Excursions in the Bristol District. University of Bristol Printing Unit, Bristol.

HARRIS, T.M. 1937. The fossil flora of Scoresby Sound East Greenland, Part 5: Stratigraphic relations of the plant beds. Meddelelser om Grønland, 112, $1-112$.

Hesselbo, S.P. \& Jenkyns, H.C. 1995. A comparison of the Hettangian to Bajocian successions of Dorset and Yorkshire. In: TAYLOR, P.D. (ed.) Field Geology of the British Jurassic. Geological Society, London, 105-150.

Hesselbo, S.P., Robinson, S.A., Surlyk, F. \& Piasecki, S. 2002. Terrestrial and marine extinction at the Triassic-Jurassic boundary synchronized with major carbon-cycle perturbation: a link to initiation of massive volcanism? Geology, 30, 251-254

Hesselbo, S.P., Morgans-Bell, H.S., McElwain, J.C., Rees, P.Mc.A., RobinSon, S.A. \& Ross, C.E. 2003. Carbon-cycle perturbation in the Middle Jurassic and accompanying changes in the terrestrial paleoenvironment. Journal of Geology, 111, 259-276.

Hodges, P. 1994. The base of the Jurassic System: new data on the first appearance of Psiloceras planorbis in southwest Britain. Geological Magazine, 131, $841-844$.

Hodych, J.P. \& DunNing, G.R. 1992. Did the Manicouagan impact trigger end-ofTriassic mass extinction? Geology, 20, 51-54.

Horton, A., Poole, E.G., Williams, B.J., Illing, V.C. \& Hobson, G.D. 1987. Geology of the Country around Chipping Norton. Memoir of the British Geological Survey, Sheet 218 (England and Wales), HMSO, London, 218.

Hounslow, M.W., Warrington, G. \& Posen, P.E. 2001. Magnetostratigraphic correlation of marine (UK) and non-marine (USA) Triassic/Jurassic boundary successions. Abstract and Poster, Earth Systems Science, Edinburgh.

Hounslow, M.W., Posen, P.E. \& Warrington, G. 2004. Magnetostratigraphy and biostratigraphy of the Upper Triassic and lowermost Jurassic succession, St. Audrie's Bay, U.K. Palaeogeography, Palaeoclimatology, Palaeoecology, in press.

IvimeY-CooK, H.C. 1974. The Permian and Triassic deposits of Wales. In: Owen, T.R. (ed.) The Upper Palaeozoic and Post-Palaeozoic Rocks of Wales. University of Wales Press, Cardiff, 295-321

Ivimey-Cook, H.C., Gaunt, G.D., Green, G.W., Horton, A., Warrington, G. \& Whittaker, A. 1980. The Triassic-Jurassic boundary in Great Britain: correspondence. Geological Magazine, 117, 617-618.

Ivimey-Cook, H.C., Hodges, P., Swift, A. \& Radley, J.D. 1999. Bivalves. In: Swift, A. \& Martill, D.M. (eds) Fossils of the Rhaetian Penarth Group. The Palaeontological Association, 83-128.

JENKYNS, H.J. \& SENIOR, J.R. 1991. Geological evidence for intra-Jurassic faulting in the Wessex Basin and its margins. Journal of the Geological Society, London, 148, 245-260.

Jenkyns, H.C. \& WiLson, P.A. 1999. Stratigraphy, paleoceanography, and evolution of Cretaceous Pacific guyots: relics from a greenhouse earth. American Journal of Science, 299, 341-392.

Kent, D.V. \& Olsen, P.E. 1999. Astronomically tuned geomagnetic polarity timescale for the Late Triassic. Journal of Geophysical Research, 104, 12831-12841.

MACQUAKer, J.H.S. 1984. Diagenetic modifications of primary sedimentological fabric in the Westbury Formation (Upper Triassic) of St Audrie's Bay, north Somerset. Proceedings of the Ussher Society, 6, 95-99.

MacquaKer, J.H.S. 1994. Palaeoenvironmental significance of 'bone-beds' in organic-rich mudstone successions: an example from the Upper Triassic of south-west Britain. Zoological Journal of the Linnean Society, 112, 285-308.

MAcquaker, J.H.S. 1999. Aspects of the sedimentology of the Westbury Formation. In: Swift, A. \& Martill, D.M. (eds) Fossils of the Rhaetian Penarth Group. The Palaeontological Association, 39-48.

Martill, D.M. 1999. Bone beds of the Westbury Formation. In: Swift, A. \& Martill, D.M. (eds) Fossils of the Rhaetian Penarth Group. The Palaeontological Association, 49-64.

Marzoli, A., Renne, P.R., Piccirillo, E.M., Ernesto, M., Bellieni, G. \& De Min, A. 1999. Extensive 200-million-year-old continental flood basalts of the Central Atlantic Province. Science, 284, 616-618.

Mayall, M.J. 1981. The Late Triassic Blue Anchor Formation and the initial Rhaetian marine transgression in south-west Britain. Geological Magazine, 118, 377-384.

MAYALl, M.J. 1983. An earthquake origin for synsedimentary deformation in a late Triassic lagoonal sequence, southwest Britain. Geological Magazine, 120, 613-622.

Mayall, M.J. \& Wright, V.P. 1981. Algal tuft structures in stromatolites from the Upper Triassic of south-west England. Palaeontology, 24, 655-660.

McElwain, J.C., Beerling, D.J. \& Woodward, F.I. 1999. Fossil plants and global warming at the Triassic-Jurassic boundary. Science, 285, 1386-1390.

McHone, J.G. 1996. Broad-terrane Jurassic flood basalts across northeastern North America. Geology, 24, 319-322.

McHone, J.G. 2000. Non-plume magmatism and rifting during the opening of the central Atlantic Ocean. Tectonophysics, 316, 287-296. 
Melville, R.V. 1956. Stratigraphical palaeontology, ammonites excluded, of the Stowell Park borehole. Bulletin of the Geological Survey of England and Wales, 11, 67-139.

Olsen, P.E., Kent, D.V. \& Sues, H.-D. ET AL. 2002. Ascent of dinosaurs linked to an iridium anomaly at the Triassic-Jurassic boundary. Science, 296, 1305-1307.

Orbell, G. 1973. Palynology of the British Rhaeto-Liassic. Bulletin of the Geological Survey, Great Britain, 44, 1-44.

Pálfy, J., Mortensen, J.K., Carter, E.S., Smith, P.L., Friedman, R.M. \& Tipper, H.W. 2000. Timing of the end-Triassic mass extinction: first on land, then in the sea? Geology, 28, 39-42.

Pálfy, J., Demény, A., Hass, J., Hetényi, M., Orchard, M.J. \& Veto, I. 2001. Carbon isotope anomaly and other geochemical changes at the TriassicJurassic boundary from a marine section in Hungary. Geology, 29, 1047-1050.

Pedersen, K.R. \& Lund, J.J. 1980. Palynology of the plant-bearing Rhaetian to Hettangian Kap Stewart Formation, Scoresby Sund, East Greenland. Review of Palaeobotany and Palynology, 31, 1-69.

Poole, E.G. 1979. The Triassic-Jurassic boundary in Great Britain. Geological Magazine, 116, 303-311.

Poole, E.G. 1980. The Triassic-Jurassic boundary in Great Britain: correspondence. Geological Magazine, 117, 619-620.

Poole, E.G. 1991. Further discussion on correlation of the Triassic-Jurassic boundary in England and Austria. Journal of the Geological Society, London, 148, 943.

Radley, J.D. \& CARPEnTER, S.C. 1999. The Late Triassic strata of Manor Farm, Aust, South Gloucestershire. Proceedings of the Bristol Naturalists' Society, 58, 57-67.

Rawson, P.F. ET AL. 2002. Stratigraphical Procedure. Professional Handbook. Geological Society, London.

Richardson, L. 1905. The Rhaetic and contiguous deposits of Glamorganshire. Quarterly Journal of the Geological Society, London, 61, 385-424.

RICHARDSON, L. 1906. On the Rhaetic and contiguous deposits of Devon and Dorset. Proceedings of the Geologists' Association, 14, 401-409.

RiCHARDSON, L. 1911. The Rhaetic and contiguous deposits of West, Mid, and part of East Somerset. Quarterly Journal of the Geological Society, London, 67, $1-74$.

RoBInson, S.A. 2002. Carbon-cycling, palaeoatmospheres and isotope stratigraphy of marginal and non-marine Mesozoic sediments. DPhil thesis, University of Oxford.

Rodine, J.R. \& Johnson, A.M. 1976. The ability of debris, heavily freighted with coarse clastic materials, to flow on gentle slopes. Sedimentology, 23, 213-234.

SANDBERG, P.A. 1983. An oscillating trend in Phanerozoic non-skeletal carbonate mineralogy. Nature, 305, 19-22.

Sephton, M.A., Amor, K., Franchi, I.A., Wignall, P.B., Newton, R. \& Zonneveld, J.P. 2002. Carbon and nitrogen isotope disturbances and an end-Norian (Late Triassic) extinction event. Geology, 30, 1119-1122.

Simms, M.J. 2003. Uniquely extensive seismite from the latest Triassic of the United Kingdom: evidence for bolide impact? Geology, 31, 557-560.

Spray, J.G., Kelley, S.P. \& Rowley, D.B. 1998. Evidence for a late Triassic multiple impact event on Earth. Nature, 392, 171-173.

SwIFT, A. 1995. A review of the nature and outcrop of the White Lias facies of the Langport Member (Penarth Group: Upper Triassic) in Britain. Proceedings of the Geologists' Association, 106, 247-258.

SwIFT, A. 1999. Stratigraphy (including biostratigraphy). In: SwIFT, A \& Martill, D.M. (eds) Fossils of the Rhaetian Penarth Group. The Palaeontological Association, 15-30.

TAnner, L.H., Hubert, J.F., Coffey, B.P. \& McInerney, D.P. 2001. Stability of atmospheric $\mathrm{CO}_{2}$ levels across the Triassic/Jurassic boundary. Nature, 411, 675-677.

Thomas, J.B., Marshall, J., Mann, A.L., Summons, R.E. \& Maxwell, J.R. 1993. Dinosteranes (4,23,24-trimethylsteranes) and other biological markers in dinoflagellate-rich marine sediments of Rhaetian age. Organic Geochemistry, 20, 91-104.

Torrens, H.S. \& GetTy, T.A. 1980. The base of the Jurassic System. In: Cope, J.C.W. (ed.) A Correlation of the Jurassic Rocks in the British Isles. Part One: Introduction and Lower Jurassic. Geological Society, London, Special Report, 14, 17-22.
Tuweni, A.O. \& Tyson, R.V. 1994. Organic facies variations in the Westbury Formation (Rhaetic, Bristol Channel Basin, SW England). Organic Geochemistry, 21, 1001-1004.

Walkden, G.M., Parker, J. \& Kelley, S.P. 2002. A Late Triassic impact ejecta layer in southwestern Britain. Science, 298, 2185-2188.

WALL, D. 1965. Microplankton, pollen and spores from the Lower Jurassic in Britain. Micropalaeontology, 11, 151-190.

Ward, P.D., Haggart, J.W., Carter, E.S., Wilbur, D., Tipper, H.W. \& Evans, T. 2001. Sudden productivity collapse associated with the Triassic-Jurassic boundary mass extinction. Science, 292, 1148-1151.

Warrington, G. \& IvimeY-CooK, H.C. 1995. The Late Triassic and Early Jurassic of Coastal Sections in West Somerset and South and Mid-Glamorgan. In: TAYLOR, P.D. (ed.) Field Geology of the British Jurassic. Geological Society, London, 9-30.

Warrington, G. \& Whittaker, A. 1984. The Blue Anchor Formation (late Triassic) in Somerset. Proceedings of the Ussher Society, 6, 100-107.

Warrington, G., Audley, M.G. \& Elliott, R.E. et AL. 1980. A Correlation of Triassic Rocks in the British Isles. Geological Society of London, Special Report, 13.

Warrington, G., Cope, J.C.W. \& Ivimey-Cook, H.C. 1994. St Audrie's Bay, Somerset, England: a candidate Global Stratotype Section and Point for the base of the Jurassic System. Geological Magazine, 133, 191-200.

Warrington, G., Ivimey-Cook, H.C., Edwards, R.A. \& Whittaker, A. 1995. The Late Triassic-Early Jurassic succession at Selworthy, west Somerset, England. Proceedings of the Ussher Society, 8, 426-432.

Waterhouse, H.K. 1999. Regular terrestrially derived palynofacies cycles in irregular marine sedimentary cycles, Lower Lias, UK. Journal of the Geological Society, London, 156, 1113-1124.

WeEdon, G.P. 1985. Hemipelagic shelf sedimentation and climatic cycles: the basal Jurassic (Blue Lias) of south Britain. Earth and Planetary Science Letters, 76, 321-335.

Weedon, G.P., Jenkyns, H.C., Coe, A.L. \& Hesselbo, S.P. 1999. Astronomical calibration of the Jurassic time scale from cyclostratigraphy in British mudrock formations. Philosophical Transactions of the Royal Society of London, Series A, 357, 1787-1813.

Weissert, H., Lini, A., Follmi, K.B. \& Kuhn, O. 1998. Correlation of Early Cretaceous carbon isotope stratigraphy and platform drowning events: a possible link? Palaeogeography, Palaeoclimatology, Palaeoecology, 137, 189-203.

Whittaker, A. 1978. The lithostratigraphical correlation of the uppermost Rhaetic and lowermost Liassic strata of the W. Somerset and Glamorgan areas. Geological Magazine, 115, 63-67.

Whittaker, A. \& Green, G.W. 1983. Geology of the Country around Weston-Super-Mare. Memoirs of the Geological Survey of Great Britain, Sheet 279 with Parts of Sheets 263 and 295 (England and Wales), HMSO, London, 295.

Wignall, P.B. 2001. Sedimentology of the Triassic-Jurassic boundary beds in Pinhay Bay (Devon, SW England). Proceedings of the Geologists' Association, 112, 349-360.

Williams, C.J., Hesselbo, S.P., Jenkyns, H.C. \& Morgans-Bell, H.S. 2001. Quartz silt in mudrocks as a key to sequence stratigraphy (Kimmeridge Clay Formation, Late Jurassic, Wessex Basin, UK). Terra Nova, 13, 449-455.

Wilson, D., Davies, J.R., Fletcher, C.J.N. \& Smith, M. 1990. Geology of the South Wales Coalfield, Part VI, the Country around Bridgend. Memoir of the British Geological Survey, Sheet 261 and 262 (England and Wales), HMSO, London, 262.

Woollam, R. \& Riding, J.B. 1983. Dinoflagellate Cyst Zonation of the English Jurassic. Report of the Institute of Geological Sciences, 83/2.

Wright, V.P. \& BurchetTE, T.P. 1996. Shallow-water carbonate environments. In: Reading, H.G. (ed.) Sedimentary Environments: Processes, Facies and Stratigraphy. Blackwell Science, Oxford, 325-394.

Wright, V.P. \& Mayall, M.J. 1981. Organism-sediment interactions in stromatolites: an example from the Upper Triassic of south-west Britain. In: Monty, C. (ed.) Phanerozoic Stromatolites-Case Studies. Springer, Berlin, 74-84.

ZIEgler, P.A. 1990. Geological Atlas of Western and Central Europe. Shell Internationale, The Hague. 